\title{
Synthesis of Some Members of the Hydroxylated Phenanthridone Sub-class of the Amaryllidaceae Alkaloid Family
}

\author{
Albert Padwa* and Hongjun Zhang \\ Department of Chemistry, Emory University, Atlanta, Georgia 30322
}

\begin{abstract}
The total synthesis of several members of the hydroxylated phenanthridone sub-class of the Amaryllidaceae alkaloid family has been carried out. ( \pm )-Lycoricidine and ( \pm )-7-deoxypancratistatin were assembled through a one-pot Stille/intramolecular Diels-Alder cycloaddition cascade to construct the core skeleton. The initially formed [4+2]-cycloadduct undergoes nitrogen-assisted ring opening followed by a deprotonation/reprotonation of the resulting zwitterion to give a rearranged hexahydroindolinone on further heating at $160{ }^{\circ} \mathrm{C}$. The stereochemical outcome of the IMDAF cycloaddition has the side arm of the tethered vinyl group oriented exo with respect to the oxygen bridge. The resulting cycloadduct was used for the stereocontrolled installation of the remaining functionality present in the C-ring of the target molecules. Key features of the synthetic strategy include (1) a lithium-hydroxide induced tandem hydrolysis/decarboxylation/elimination sequence to introduce the required $\pi$-bond in the $\mathrm{C}$-ring of ( \pm -lycoricidine; and (2) conversion of the initially formed Diels-Alder adduct into an aldehyde intermediate which then undergoes a stereospecific decarbonylation reaction mediated by Wilkinson's catalyst to set the trans B-C ring junction of ( \pm )-7deoxypancratistatin.
\end{abstract}

The Amaryllidaceae alkaloids constitute an important class of naturally-occurring compounds. ${ }^{1}$ The lycorine-type alkaloids, which are characterized by the presence of the galanthan ring system (1), represent a significant sub-class within the Amaryllidaceae family. ${ }^{2}$ This group of compounds has attracted the attention of synthetic chemists due to the interesting biological properties of some of its members (Figure 1). ${ }^{3}$ Several of these alkaloids possess antineoplastic and antimicotic activities while others are known to exhibit insect antifeedant activity. ${ }^{1}$ Lycorine (2) was first isolated in 1877 and was shown to be a powerful inhibitor of growth and cell division in higher plants and also to possess antiviral activity. ${ }^{4,5}$ The tetracyclic pyrrolo $[d, e]$-phenanthridine (galanthan) skeleton has been of considerable interest to organic chemists ever since the structure of lycorine was established by Uyeo and Wildman in $1955 .{ }^{6}$ While many lycorine-type alkaloids possess a trans-B,C ring juncture (e.g. lycorine (2), $\alpha$-lycorane (3)), compounds with a cis-B,C ring juncture such as that found in $\gamma$-lycorane (4) are also known (see also: fortucine (5); siculinine (6)). ${ }^{7}$ The history of the related hydroxylated phenanthridones of the Amaryllidaceae group, their biological profiles and various syntheses have been reviewed on several occasions, ${ }^{8}$ most recently by Hudlicky and Rinner in 2005.9 Lycoricidine (7), ${ }^{10}$ the structurally related narciclasine (8), 11 as well as pancratistatin (9) ${ }^{12}$ and 7-deoxypancratistatin (10) ${ }^{13}$ are popular synthetic targets primarily because their heterocyclic framework provides a means to demonstrate the utility of new synthetic strategies. ${ }^{9}$ In addition, the narcissus alkaloids are available only in small quantities from natural sources $^{14}$ and their use as therapeutic agents ${ }^{15}$ depends on their ready availability. 
Among the many approaches to the Amaryllidaceae alkaloids, 9,16 the Diels-Alder cycloaddition reaction has played a key role in the preparation of the $\mathrm{C}$-ring of these natural products. 17,18 Application of the intramolecular Diels-Alder reaction for the construction of aza-polycyclic compounds has been practiced for more than two decades 19,20 and interest in this methodology has been reinforced over the past several years. ${ }^{21}$ Heterocycles such as furan, thiophene, and pyrrole undergo Diels-Alder reactions despite their stabilized 6- $\pi$ aromatic electronic configuration. ${ }^{22}$ The furan ring generally shows low reactivity toward unactivated dienophiles, and the competing retro Diels-Alder reaction often becomes a problem from a synthetic point of view. ${ }^{22}$ However, placement of the furan ring and the dienophile in the same molecule can often circumvent these problems. ${ }^{23,24}$ Our synthetic strategy directed towards the hydroxylated phenanthridone type alkaloids was to take advantage of the intramolecular Diels-Alder reaction of an alkenyl substituted 2-amidofuran (IMDAF), as had been outlined in earlier reports from this laboratory. ${ }^{25}$ Our retrosynthetic analysis of $( \pm)$-lycoricidine $(7)$ is shown in Scheme 1 and makes use of a tandem cascade sequence consisting of a Stille coupling 26 followed by a spontaneous intramolecular [4+2]-cycloaddition of an amidofuran. The resulting cycloadduct $\mathbf{1 3}$ is then used for the stereocontrolled installation of the other functionality present in the C-ring of $( \pm)$-lycoricidine. The carbomethoxy substituent would be utilized as the critical control element not only to facilitate the [4+2]-cycloaddition but also to provide a handle for the introduction of the required $\pi$-bond and to set the stereochemistry at the $\mathrm{C}_{4 \mathrm{a}}$-ring junction. In the present paper we document the results of our studies making use of this methodology. 27

\section{Results and Discussion}

\section{Model Studies}

As a prelude to the total synthesis of $( \pm$ )-lycoricidine (7), we initially set out to prepare the core hydroxylated phenanthridone skeleton in order to test the viability of our approach as well as to probe specific reactions to be used in a total synthesis effort. With this in mind, we first investigated the thermolysis of the prototypic system $\mathbf{1 5}$ prepared according to the sequence of reactions outlined in Scheme 2.

The thermolysis of 2-amidofuran 15 at $160{ }^{\circ} \mathrm{C}$ resulted in a major reorganization that gave rise to dihydrophenanthridine-dione $\mathbf{1 8}$ in $70 \%$ yield. When the thermolysis was carried out at 80 ${ }^{\circ} \mathrm{C}$, we were pleased to discover that the desired Diels-Alder cycloadduct $\mathbf{1 6}$ was formed in quantitative yield. This IMDAF cycloaddition proceeded by a transition state where the side arm of the tethered vinyl group is oriented exo with respect to the oxygen bridge. ${ }^{24}$

Consequently, the carbomethoxy group and oxy bridge in the product are disposed in an anti relationship. Further heating of cycloadduct 16 at $160{ }^{\circ} \mathrm{C}$ resulted in a smooth reorganization to afford the rearranged product 18 in high yield. This reaction cascade can be accounted for by a nitrogen-assisted ring opening of $\mathbf{1 6}$ to give zwitterion $\mathbf{1 7}$ as a transient intermediate. A subsequent deprotonation/reprotonation of $\mathbf{1 7}$ accounts for the formation of $\mathbf{1 8 .}$

In our planned approach toward ( \pm )-lycoricidine (7), we needed to install the other functional groups present on the C-ring with the correct stereochemistry. The first step in our conceived synthesis of $( \pm)$-lycoricidine (7) requires a stereochemically controlled dihydroxylation of the $\pi$-bond present in the Diels-Alder cycloadduct. This tactic was easily tested using the readily available cycloadduct 16. Treatment of 16 with catalytic $\mathrm{OsO}_{4}$ in the presence of 4-methylmorpholine- $N$-oxide furnished the desired diol 19 in $95 \%$ yield (Scheme 4 ). The dihydroxylation reaction occurred exclusively from the less hindered exo face. In our attempts to convert diol 19 into the corresponding acetonide, a rather unusual acid-catalyzed rearrangement occurred when the reaction was performed in methanol containing a trace amount of $p$-toluenesulfonic acid. The major and unexpected product obtained from this reaction ( $81 \%$ yield) was identified as enone $\mathbf{2 0}$ on the basis of its spectral data. This unusual 
reorganization can be rationalized by the cascade pathway proposed in Scheme 5. We assume that the first step proceeds by an acid-catalyzed oxabicyclic ring opening which is assisted by the electron pair of the amido nitrogen. A subsequent deprotonation would generate enol 22 which might very well transfer the Boc group on the adjacent carbamate, followed by loss of water to produce $\mathbf{2 3}$ as a transient species. This step is not essential for the overall reaction to occur since some variation in timing is certainly possible. Addition of methanol to the highly reactive imino functionality present in $\mathbf{2 3}$ would lead to $t$-butyl vinyl carbonate $\mathbf{2 4}$. Hydrolysis of the acid sensitive carbonate with simultaneous elimination of water accounts for the formation of the observed product $\mathbf{2 0 .}$

As a consequence of the acid lability of diol 19 we decided to replace the Boc with a benzyl group in order to avoid the acid-catalyzed cascade reaction encountered with 19 . The synthesis of the $N$-benzyl cycloadduct 25 proceeded along similar lines to that described above. In this case, the methyl acrylate moiety was introduced by means of a Stille coupling 26 using methyl 2-tri- $n$-butyl stannylacrylate. ${ }^{28}$ The optimal conditions for this reaction were eventually determined to be those described by Baldwin. ${ }^{29}$ The expected cross-coupled amidofuran, however, was not isolated as it spontaneously underwent an intramolecular [4+2]-

cycloaddition to furnish cycloadduct $\mathbf{2 5}$ in $55 \%$ overall yield for the two-step cascade. The increased reactivity of the $N$-benzyl amidofuran $\left(55^{\circ} \mathrm{C}\right)$ when compared to the Boc analogue $\left(80{ }^{\circ} \mathrm{C}\right)$ is probably related to a higher lying HOMO of the furanyl $4 \pi$-system. The subsequent dihydroxylation reaction proceeded as expected with exclusive exo-stereoselectivity to give diol 26 (Scheme 6). In order to minimize acid degradation pathways, we chose to induce the opening of the oxabicyclic ring prior to the protection of the $\mathrm{C}_{3}, \mathrm{C}_{4}$-hydroxyl groups. The expected $N$-acyliminium ion was generated by treating 26 with $\mathrm{BF}_{3} \cdot \mathrm{OEt}_{2}$ and the incipient cation was reduced in situ using $\mathrm{Et}_{3} \mathrm{SiH}$ to give triol 27 in $74 \%$ yield. The presence of the angular carbomethoxy group directs the hydride delivery from the less hindered $\beta$-face and sets the correct stereochemistry at $\mathrm{C}_{4 \mathrm{a}}$ that is needed for $( \pm$ )-lycoricidine (7). Selective esterification of the $\mathrm{C}_{2}$ hydroxyl group with $\mathrm{AcCl} / \mathrm{Net}_{3}$ followed by protection of the remaining two hydroxyl groups with 2,2-dimethoxy-propane in the presence of $p$ - $\mathrm{TsOH}$ provided acetonide $\mathbf{2 8}$ whose structure was unequivocally established by X-ray crystallography. The acetoxy group present in compound $\mathbf{2 8}$ was hydrolyzed with $\mathrm{NaOMe}$ and the resulting alcohol was then treated with $\mathrm{NaH}$ followed by the addition of $\mathrm{CS}_{2}$ and Mel to afford the corresponding xanthate. Heating the xanthate in 1,2-dichlorobenzene for $12 \mathrm{~h}$ afforded the expected olefin 29 derived from a Chugaev elimination 30 in $92 \%$ yield.

Since the $\beta$-face of the double bond in compound $\mathbf{2 9}$ is blocked by the bulky acetonide, the dihydroxylation reaction was expected to take place from the less hindered $\alpha$-face, syn to the carbomethoxy group, thereby setting the correct stereochemistry of the $\mathrm{C}_{2}$-hydroxyl group needed for an eventual synthesis of ( \pm )-lycoricidine (7). Indeed, when 29 was treated with $\mathrm{OsO}_{4} / \mathrm{NMO}$, the desired diol $\mathbf{3 0}$ was formed as a transient species but underwent spontaneous cyclization with the adjacent carbomethoxy group to deliver $\gamma$-lactone 31 (Scheme 7). A subsequent mesylation reaction afforded mesylate 32 in 74\% yield for the two-step sequence starting from 29. With compound 32 in hand, we hoped that we could induce a domino fragmentation cascade which would involve (a) lactone hydrolysis using $\mathrm{LiOH}$ to deliver the carboxylate anion; and (b) a subsequent decarboxylation/elimination of the mesylate group to introduce the critical double bond in the C-ring. ${ }^{31}$ Gratifyingly, this desired cascade proceeded quite smoothly and afforded the allylic alcohol $\mathbf{3 5}$ in near quantitative yield. This reaction presumably proceeds by an initial opening of the lactone ring with hydroxide to give carboxylate anion 33. A subsequent decarboxylation would generate anion $\mathbf{3 4}$ which, in turn, would induce the elimination of the mesylate anion ultimately affording the observed alcohol 35. 


\section{(士)-Lycoricidine}

Having been encouraged by the preliminary cycloaddition experiments involving furanyl carbamate 15, we turned our attention to the preparation of amidofuran $\mathbf{4 0}$ which we hoped to use for the eventual synthesis of ( \pm )-lycoricidine (7). The synthesis of $\mathbf{4 0}$ began by coupling the known acid chloride $\mathbf{3 6}^{32}$ with the lithiated carbamate $\mathbf{3 7 b}$ derived by treating furanyl-2ylcarbamic acid tert-butyl ester (37a) with $n$-BuLi. Removal of the Boc-protecting group from the resulting carbamate 38 with $\mathrm{Mg}\left(\mathrm{ClO}_{4}\right)_{2}$ afforded $\mathrm{NH}$ amide 39 in $75 \%$ yield and this was followed by reaction with $\mathrm{NaH}$ and $p$-methoxybenzyl chloride to give $\mathbf{1 1}$ in $83 \%$ yield. ${ }^{33}$ The methyl acrylate moiety was introduced by means of a Stille coupling 26 using methyl 2-tri- $n$ butyl-stannylacrylate (12) ${ }^{28}$ (Scheme 8). The optimal conditions for this reaction were eventually determined to be those described by Corey which utilized a combination of $\mathrm{CuCl} /$ $\mathrm{Pd}(0) / \mathrm{LiCl}$ for the key coupling. ${ }^{34}$ The use of DMSO with rigorous exclusion of oxygen and moisture at $60{ }^{\circ} \mathrm{C}$ gave the best results. The expected cross-coupled amidofuran 40 , however, was not isolated as it spontaneously underwent an intramolecular [4+2]-cycloaddition to furnish cycloadduct $\mathbf{1 3}$ in $82 \%$ overall yield for the two-step cascade. The increase in reactivity of 40 when compared to the related furanyl carbamates $24\left(>150{ }^{\circ} \mathrm{C}\right)$ is due to the placement of the carbonyl center within the dienophilic tether as well as the presence of the carbomethoxy group which lowers the LUMO energy of the $\pi$-bond thereby facilitating the cycloaddition. Dramatic effects on the rate of the Diels-Alder reaction were previously noted to occur when an amido group was used to anchor the diene and dienophile. ${ }^{35}$ Our ability to isolate oxabicyclic adduct $\mathbf{1 3}$ is presumably a result of the lower reaction temperature employed (i.e., $60^{\circ} \mathrm{C}$ ) as well as the presence of the amido carbonyl group, which diminishes the basicity of the nitrogen atom thereby retarding the ring cleavage/rearrangement reaction generally encountered with these systems. ${ }^{24}$

With the rapid construction of the lycoricidine framework in hand, installation of the other functional groups present on the C-ring with the correct relative stereochemistry was investigated. To continue the synthesis, cycloadduct 13 was transformed to diol 41 by reaction with catalytic $\mathrm{OsO}_{4}$ in the presence of 4-methyl-morpholine- $N$-oxide. The dihydroxylation reaction occurred exclusively from the less hindered exo face producing $\mathbf{4 1}$ in $98 \%$ yield (Scheme 9). Having introduced the correct cis-stereochemistry of the hydroxyl groups at the $\mathrm{C}_{3}, \mathrm{C}_{4}$ positions, we then proceeded to set the stereochemistry at the $\mathrm{C}_{4 \mathrm{a}}$ position, insert the remaining $\alpha$-hydroxyl group at $\mathrm{C}_{2}$ and ultimately introduce the required $\pi$-bond. All of these operations were facilitated by making use of the available carbomethoxy group (vide infra). First, diol $\mathbf{4 1}$ was converted to the corresponding acetonide $\mathbf{4 2}$ in $80 \%$ yield by treatment with 2,2-dimethoxypropane and catalytic pyridinium $p$-toluenesulfonate. The uniquely functionalized oxabicyclic adduct $\mathbf{4 2}$ contains a "masked" $N$-acyliminium ion which can be released by treatment with a Lewis acid such as TMSOTf. When the resulting ring-opened iminium ion was treated with $\mathrm{Zn}\left(\mathrm{BH}_{4}\right)_{2},{ }^{36}$ alcohol 14 was obtained with complete diastereoselectivity in $74 \%$ yield.

What was required for the end game leading to ( \pm )-lycoricidine (7) was to invert the stereochemistry of the $\mathrm{C}_{2}$-hydroxyl group, remove the carbomethoxy moiety and generate a double bond between the $\mathrm{C}_{1}-\mathrm{C}_{10 \mathrm{~b}}$ position of the $\mathrm{C}$-ring. To this end, compound $\mathbf{1 4}$ was treated with $\mathrm{NaH}$ followed by the addition of $\mathrm{CS}_{2}$ and Mel to give the corresponding xanthate ester which, upon heating at reflux in 1,2-dichlorobenzene for $12 \mathrm{~h}$, afforded the expected olefin $\mathbf{4 3}$ derived from a Chugaev elimination ${ }^{30}$ in $94 \%$ yield (Scheme 10). Since the $\beta$-face of the $\pi$-bond of $\mathbf{4 3}$ was blocked by the bulky acetonide, a dihydroxylation reaction was expected to take place from the less hindered $\alpha$-face (syn to the carbomethoxy group), thereby setting the correct stereochemistry of the $\mathrm{C}_{2}$-hydroxyl group. Indeed, when $\mathbf{4 3}$ was treated with $\mathrm{OsO}_{4} /$ $\mathrm{NMO}$, the desired diol $\mathbf{4 4}$ was formed as a transient species but underwent spontaneous cyclization with the adjacent carbomethoxy group to deliver $\gamma$-lactone $\mathbf{4 5}$. A subsequent 
mesylation reaction afforded mesylate 46 in $76 \%$ yield for the two-step sequence starting from 43. The $\gamma$-lactonization of $\mathbf{4 4}$ to $\mathbf{4 5}$ permits the selective activation of the $\mathrm{C}_{1}$-hydroxyl group. The PMB group was removed by the reaction of 46 with $\mathrm{PdCl}_{2}$ in the presence of acetic acid $^{37}$ to furnish the deprotected amide in $65 \%$ yield. Gratifyingly, the reaction of this amide with $\mathrm{LiOH}$ in aqueous THF induced the tandem hydrolysis/decarboxylation/elimination sequence, ${ }^{31}$ previously encountered with the model substrate $\mathbf{3 2}$, to furnish allylic alcohol 47 in $93 \%$ yield. Finally, deprotection of the acetonide with TFA afforded ( \pm )-lycoricidine (7) in $90 \%$ yield.

\section{(士)-7-Deoxypancratistatin}

The potent antiviral properties associated with the hydroxylated phenanthridone 7deoxypancratistatin (10) ${ }^{38}$ coupled with its limited availability from natural resources and decreased toxicity relative to pancratistatin $(9)^{39}$ have prompted significant efforts toward its total synthesis. ${ }^{40}$ The main challenge towards designing any synthetic strategy toward deoxypancratistatin lies in the control of the trans-fused $\mathrm{B}-\mathrm{C}$ ring junction $\left(\mathrm{C}_{4 \mathrm{a}}, \mathrm{C}_{10 \mathrm{~b}}\right)$ and with the stereocontrolled installation of continuous hydroxy functionalities located around the perimeter of the $\mathrm{C}$ ring moiety. The trans $\mathrm{B}-\mathrm{C}$ ring junction is believed to be critical for its anticancer activity ${ }^{15}$ but is much more difficult to generate than the thermodynamically more stable $c$ is ring junction. ${ }^{8}$ For example, Rigby and co-workers have observed a decided preference for the cis fusion in the related pancratistatin intermediate 49 which was readily formed by epimerization of the less stable trans isomer $\mathbf{4 8}$ at room temperature (Scheme 11). 41

Our plan for the synthesis of 7-deoxypancratistatin (10) was to convert alcohol 14, which had previously been used as an intermediate in the total synthesis of $( \pm)$-lycoricidine $(7)$, into the corresponding aldehyde 50. We reasoned that the trans $\mathrm{B}-\mathrm{C}$ ring junction could be established through a $\mathrm{RhCl}\left(\mathrm{PPh}_{3}\right)_{3}$ promoted decarbonylation reaction of this aldehyde. ${ }^{42}$ Under the influence of transition metal compounds, aldehydes are known to readily undergo decarbonylation and produce the corresponding saturated hydrocarbons. ${ }^{42}$ Rhodium complexes such as Wilkinson's catalyst $\mathrm{RhCl}\left(\mathrm{PPh}_{3}\right)_{3}$ are most often employed in both stoichiometric and catalytic reactions to effect the decarbonylation. ${ }^{42,43}$ The earlier seminal studies by Walborsky ${ }^{42 b}$ demonstrated that the decarbonylation reaction using Wilkinson's catalyst proceeds with retention of configuration and this finding has been used by others in complex natural product synthesis. ${ }^{43}$ With this in mind, we set out to convert the carbomethoxy group present in $\mathbf{1 4}$ to the corresponding aldehyde. Our first attempt to prepare aldehyde $\mathbf{5 0}$ involved the reduction of 14 with DIBAL. However, the expected aldehyde (or alcohol) was not produced but instead amine $\mathbf{5 1}$ was obtained in high yield as the exclusive product (Scheme 12). The increased reactivity of the amido carbonyl group over the ester toward DIBAL reduction is probably related to a significant decrease in the strain energy of ring $\mathrm{B}$ by changing the hybridization from $\mathrm{sp}^{2}$ to $\mathrm{sp}^{3}$ at the $\mathrm{C}_{6}$ position. ${ }^{44}$ This undesired reduction could be circumvented by converting the ester group into the corresponding acid chloride after protecting the free $\mathrm{OH}$ group as the benzyl ether. Selective reduction of the acid chloride with $\mathrm{Zn}\left(\mathrm{BH}_{4}\right)_{2}$ followed by a subsequent oxidation of the resulting alcohol using Ley's procedure $^{45}$ afforded the desired aldehyde 50. When a solution of $\mathbf{5 0}$ and $\mathrm{RhCl}\left(\mathrm{PPh}_{3}\right)_{3}$ was heated in benzonitrile at reflux, the decarbonylation reaction proceeded to give the desired trans-fused lactam 52 in $63 \%$ yield.

With the rapid construction of the trans-fused lactam in hand, installation of the other functional groups present on the C-ring with the correct relative stereochemistry was next investigated. What was required for the end game was to introduce a $\mathrm{C}_{1}$-hydroxyl group and also to invert the stereochemistry at the $\mathrm{C}_{2}$-position. To this end, a transient double bond between $\mathrm{C}_{1}$ and $\mathrm{C}_{2}$ was installed by carrying out a debenzylation under hydrogenolysis conditions followed by 
a Chugaev elimination 30 of the xanthate ester which proceeded in $85 \%$ overall yield (Scheme 13). Since the presence of the bulky acetonide moiety partially blocked the $\beta$-face of the $\pi$ bond of 53, dihydroxylation occurred preferentially from the less hindered $\alpha$-face to furnish two easily separable diol isomers (3:1) in almost quantitative yield. A subsequent regioselective inversion of the stereochemistry at the $\mathrm{C}_{1}$-hydroxyl group of the major diol $\mathbf{5 4}$ was achieved through a three-step sequence. ${ }^{12 \mathrm{c}}$ Treatment of diol $\mathbf{5 4}$ with thionyl chloride followed by oxidation of the resulting sulfite with $\mathrm{NaIO}_{4}$ in the presence of catalytic $\mathrm{RuCl}_{3}$ furnished sulfate $\mathbf{5 5}$ in $82 \%$ yield. ${ }^{46}$ Reaction of sulfate $\mathbf{5 5}$ with cesium benzoate followed by acid hydrolysis resulted in the formation of triol $\mathbf{5 6}$ in $\mathbf{7 5 \%}$ yield. The final ester hydrolysis and amide deprotection proceeded uneventfully to furnish 7-deoxypancratistatin (10) in $80 \%$ yield.

In conclusion, we have developed a new type of cross-coupling/cycloaddition cascade which has been successfully utilized in the total synthesis of several members of the hydroxylated phenanthridone sub-class of the Amaryllidaceae alkaloid family. These alkaloids were assembled by a one-pot Stille/intramolecular Diels-Alder cycloaddition cascade to construct the core skeleton. The resulting cycloadduct was then used for the stereocontrolled installation of the other functionality present in the C-ring of the target molecules. Key features of the synthetic strategy include (1) a lithium hydroxide induced tandem hydrolysis/decarboxylation/ elimination sequence to introduce the required $\pi$-bond in the C-ring of ( \pm -lycoricidine; and (2) conversion of the initially formed Diels-Alder adduct into an aldehyde intermediate which is then induced to undergo a stereospecific decarbonylation reaction using Wilkinson's catalyst to set the trans B-C ring junction of ( \pm -)-7-deoxypancratistatin. We plan to use this and related cascade methodology in approaches to other natural product targets, the results of which will be disclosed in due course.

\section{Experimental Section}

\section{2-[2-(tert-Butoxycarbonyl-furan-2-yl-aminocarbonyl)phenyl]acrylic Acid Methyl Ester (15)}

To a suspension of $0.40 \mathrm{~g}(1.9 \mathrm{mmol})$ of 2-(1 -methoxycarbonylvinyl)-benzoic acid 47 in $4 \mathrm{~mL}$ of $\mathrm{CH}_{2} \mathrm{Cl}_{2}$ at $\mathrm{rt}$ was added dropwise $0.25 \mathrm{~mL}$ ( $\left.2.9 \mathrm{mmol}\right)$ of oxalyl chloride and several drops of DMF as a catalyst. The reaction mixture was stirred at $\mathrm{rt}$ for $3 \mathrm{~h}$ and then concentrated under reduced pressure. The residue was taken up in $4 \mathrm{~mL}$ of THF and was used for the next step without further purification. In a separate flask containing $0.39 \mathrm{~g}(2.1 \mathrm{mmol})$ of furan-2-ylcarbamic acid furan-2-tert-butyl ester (37a) and $5 \mathrm{~mL}$ of THF at $0{ }^{\circ} \mathrm{C}$ was added $0.9 \mathrm{~mL}(2.3$ $\mathrm{mmol}$ ) of $n-\operatorname{BuLi}(2.5 \mathrm{M}$ in hexane). After stirring for $20 \mathrm{~min}$, the solution was added dropwise to the above acid choride solution at $0{ }^{\circ} \mathrm{C}$. The reaction mixture was stirred at $0{ }^{\circ} \mathrm{C}$ for $20 \mathrm{~min}$, diluted with $\mathrm{H}_{2} \mathrm{O}$, and extracted with EtOAc. The combined organic extracts were washed with $\mathrm{H}_{2} \mathrm{O}$, brine, dried over $\mathrm{MgSO}_{4}$, and concentrated under reduced pressure. The residue was subjected to flash silica gel chromatography to give $0.46 \mathrm{~g}$ (64\%) of amidofuran 15; IR (neat) $1748,1724,1238$, and $1153 \mathrm{~cm}^{-1 ; 1} \mathrm{H}-\mathrm{NMR}\left(\mathrm{CDCl}_{3}, 600 \mathrm{MHz}\right) \delta 1.28(\mathrm{~s}, 9 \mathrm{H}), 3.75(\mathrm{~s}, 3 \mathrm{H})$, $5.86(\mathrm{~s}, 1 \mathrm{H}), 6.23(\mathrm{~d}, 1 \mathrm{H}, J=3.0 \mathrm{~Hz}), 6.39(\mathrm{~s}, 1 \mathrm{H}), 6.57(\mathrm{~s}, 1 \mathrm{H}), 7.30(\mathrm{~d}, 1 \mathrm{H}, J=7.8 \mathrm{~Hz}), 7.33$ $(\mathrm{s}, 1 \mathrm{H}), 7.39(\mathrm{t}, 1 \mathrm{H}, J=7.8 \mathrm{~Hz}), 7.46(\mathrm{t}, 1 \mathrm{H}, J=7.8 \mathrm{~Hz})$, and $7.55(\mathrm{~d}, 1 \mathrm{H}, J=7.8 \mathrm{~Hz}) ;{ }^{13} \mathrm{C}-\mathrm{NMR}$ $\left(\mathrm{CDCl}_{3}, 150 \mathrm{MHz}\right) \delta 27.7,52.3,84.2,106.4,111.5,128.0,128.1,129.5,130.6,130.9,135.5$, $136.1,140.4,140.8,143.8,151.4,166.3$, and 170.9.

\section{2,4a-Epoxy-6-oxo-2,4a-dihydro-1H,6H-phenanthridine-5,10b-dicarboxylic Acid 5-tert-Butyl Ester 10b-Methyl Ester (16)}

A solution containing $0.43 \mathrm{~g}$ ( $1.2 \mathrm{~mol})$ of amidofuran $15 \mathrm{in} 2 \mathrm{~mL}$ of toluene was heated at 80 ${ }^{\circ} \mathrm{C}$ for $3 \mathrm{~h}$. After cooling to room temperature, the reaction mixture was concentrated under reduced pressure to give cycloadduct 16 in $98 \%$ yield as a white solid; mp $133-134{ }^{\circ} \mathrm{C}$; IR (neat) $1735,1684,1369,1256$, and $1150 \mathrm{~cm}^{-1 ; 1} \mathrm{H}-\mathrm{NMR}\left(\mathrm{CDCl}_{3}, 600 \mathrm{MHz}\right) \delta 1.58(\mathrm{~s}, 9 \mathrm{H})$, $2.53(\mathrm{dd}, 1 \mathrm{H}, J=12.0$ and $4.8 \mathrm{~Hz}), 2.80(\mathrm{~d}, 1 \mathrm{H}, J=12.0 \mathrm{~Hz}), 3.60,(\mathrm{~s}, 3 \mathrm{H}), 4.95(\mathrm{dd}, 1 \mathrm{H}, J=4.8$ 
and $1.8 \mathrm{~Hz}), 6.35(\mathrm{~d}, 1 \mathrm{H}, J=5.4 \mathrm{~Hz}), 6.50(\mathrm{dd}, 1 \mathrm{H}, J=5.4$ and $1.8 \mathrm{~Hz}), 7.33(\mathrm{~d}, 1 \mathrm{H}, J=7.8 \mathrm{~Hz})$, $7.40(\mathrm{dt}, 1 \mathrm{H}, J=7.8$ and $1.2 \mathrm{~Hz}), 7.53(\mathrm{dt}, 1 \mathrm{H}, J=7.8$ and $1.2 \mathrm{~Hz})$, and $8.20(\mathrm{dd}, 1 \mathrm{H}, J=7.8$ and $1.2 \mathrm{~Hz}) ;{ }^{13} \mathrm{C}-\mathrm{NMR}\left(\mathrm{CDCl}_{3}, 150 \mathrm{MHz}\right) \delta 28.0,41.8,53.1,54.9,75.7,84.8,97.4,126.4,128.3$, 128.6, 129.8, 133.8, 134.3, 136.1, 139.8, 152.1, 162.5, and 171.4; Anal. Calcd for $\mathrm{C}_{20} \mathrm{H}_{21} \mathrm{NO}_{6}$ : C, 64.68; H, 5.70; N, 3.77. Found: C, 64.61; H, 5.78; N, 3.81.

\section{2,6-Dioxo-2,3-dihydro-1H,6H-phenanthridine-5,10b-dicarboxylic Acid 5-tert-butyl Ester 10b- Methyl Ester (18)}

In a sealed tube was added $0.03 \mathrm{~g}(0.09 \mathrm{mmol})$ of cycloadduct 16 and $1.5 \mathrm{~mL}$ of benzene. The mixture was purged with argon, sealed, and heated at $160{ }^{\circ} \mathrm{C}$ for $4 \mathrm{~h}$. After cooling to rt, the solvent was removed under reduced pressure and the residue was subjected to flash silica gel chromatography to give $0.03 \mathrm{~g}(80 \%)$ of 18 as a clear oil; IR (neat) 1766,1733,1244, and 1147 $\mathrm{cm}^{-1 ; 1} \mathrm{H}-\mathrm{NMR}\left(\mathrm{CDCl}_{3}, 600 \mathrm{MHz}\right) \delta 1.59(\mathrm{~s}, 9 \mathrm{H}), 2.77(\mathrm{~d}, 1 \mathrm{H}, J=15.0 \mathrm{~Hz}), 3.13(\mathrm{~d}, 1 \mathrm{H}, J=$ $3.9 \mathrm{~Hz}), 3.59(\mathrm{~d}, 1 \mathrm{H}, J=15.0 \mathrm{~Hz}), 3.64(\mathrm{~s}, 3 \mathrm{H}), 5.61(\mathrm{t}, 1 \mathrm{H}, J=3.9 \mathrm{~Hz}), 7.28(\mathrm{dd}, 1 \mathrm{H}, J=7.8$ and $1.5 \mathrm{~Hz}), 7.48(\mathrm{td}, 1 \mathrm{H}, J=7.8$ and $1.5 \mathrm{~Hz}), 7.60(\mathrm{td}, 1 \mathrm{H}, J=7.8$ and $1.5 \mathrm{~Hz}), 8.21(\mathrm{dd}, 1 \mathrm{H}$, $J=7.8$ and $1.5 \mathrm{~Hz}) ;{ }^{13} \mathrm{C}-\mathrm{NMR}\left(\mathrm{CDCl}_{3}, 100 \mathrm{MHz}\right) \delta 27.8,37.8,47.0,50.3,53.9,85.4,111.0$, $124.9,126.7,128.9,129.5,132.4,134.1,137.6,151.3,160.6,170.4$, and 203.5.

\section{4a-Methoxy-4,6-dioxo-4,4a,5,6-tetrahydro-1H-phenanthridine-10b-carboxylic Acid Methyl Ester (20)}

To a solution containing $0.05 \mathrm{~g}(0.14 \mathrm{mmol})$ of cycloadduct 16 in a $2 \mathrm{~mL}$ of a 2:1:1 -mixture of $\left.\mathrm{THF} / \mathrm{H}_{2} \mathrm{O} / \mathrm{t}-\mathrm{BuOH}\right)$ was added $0.03 \mathrm{~g}(0.23 \mathrm{mmol})$ of $\mathrm{NMO}(N$-methyl morpholine- $N$-oxide $)$ and catalytic $\mathrm{OsO}_{4}$. After stirring for $1 \mathrm{~h}$ at $\mathrm{rt}$, the mixture was diluted with $\mathrm{H}_{2} \mathrm{O}$ and extracted with $\mathrm{CH}_{2} \mathrm{Cl}_{2}$. The combined organic extracts were washed with $\mathrm{H}_{2} \mathrm{O}$, brine, and dried over $\mathrm{MgSO}_{4}$. Concentration under reduced pressure provided the expected diol 19 in $95 \%$ yield as a clear oil which was used in the next step without further purification; ${ }^{1} \mathrm{H}-\mathrm{NMR}\left(\mathrm{CDCl}_{3}, 400\right.$ $\mathrm{MHz}) \delta 1.48(\mathrm{~s}, 9 \mathrm{H}), 2.48(\mathrm{dd}, 1 \mathrm{H}, J=13.2$ and $6.8 \mathrm{~Hz}), 3.06(\mathrm{~d}, 1 \mathrm{H}, J=13.2 \mathrm{~Hz}), 3.57(\mathrm{~s}, 3 \mathrm{H})$, $4.06(\mathrm{~d}, 1 \mathrm{H}, J=6.0 \mathrm{~Hz}), 4.40$ (d, 1H, J=6.4 Hz), 4.92 (d, 1H, J=6.0 Hz), 7.09 (s, 1H), 7.16 (d, $1 \mathrm{H}, J=7.6 \mathrm{~Hz}), 7.40(\mathrm{dt}, 1 \mathrm{H}, J=7.6$ and $1.2 \mathrm{~Hz}), 7.52(\mathrm{dt}, 1 \mathrm{H}, J=7.6$ and $1.2 \mathrm{~Hz}), 8.15(\mathrm{~d}$, $1 \mathrm{H}, \mathrm{J}=7.6 \mathrm{~Hz}) ;{ }^{13} \mathrm{C}-\mathrm{NMR}\left(\mathrm{CDCl}_{3}, 100 \mathrm{MHz}\right) \delta 27.8,39.4,53.2,53.7,71.8,75.8,77.4,83.8$, 93.9, 126.7, 127.0, 128.3, 128.9, 133.8, 140.4, 152.6, 164.0, and 170.9.

The crude diol 19 was taken up in $1.5 \mathrm{~mL}$ of 2,2-dimethoxypropane and catalytic $p$-toluene sulfonic acid was added. The mixture was stirred at $\mathrm{rt}$ for $30 \mathrm{~min}$, quenched with a saturated $\mathrm{NaHCO}_{3}$ solution, and extracted with EtOAc. The organic extracts were washed with $\mathrm{H}_{2} \mathrm{O}$, brine, and dried over $\mathrm{MgSO}_{4}$. After concentration under reduced pressure, the residue was subjected to preparative TLC to give $0.032 \mathrm{~g}(81 \%)$ of $\mathbf{2 0}$ as a white solid; mp $200-202{ }^{\circ} \mathrm{C}$; IR (neat) 1734, 1677, and $1056 \mathrm{~cm}^{-1 ;}{ }^{1} \mathrm{H}-\mathrm{NMR}\left(\mathrm{CDCl}_{3}, 600 \mathrm{MHz}\right) \delta 3.03(\mathrm{~s}, 3 \mathrm{H}), 3.21(\mathrm{dt}$, $1 \mathrm{H}, J=18.0$ and $2.4 \mathrm{~Hz}), 3.41(\mathrm{dd}, 1 \mathrm{H}, J=18.0$ and $6.0 \mathrm{~Hz}), 3.54(\mathrm{~s}, 3 \mathrm{H}), 6.14(\mathrm{dd}, 1 \mathrm{H}, J=10.2$ and $2.4 \mathrm{~Hz}$ ), 7.02 (ddd, 1H, $J=10.2,6.0$, and $2.4 \mathrm{~Hz}$ ), 7.33 (brs, 1H), 7.45 (d, 1H, $J=7.8 \mathrm{~Hz}$ ), $7.48(\mathrm{t}, 1 \mathrm{H}, J=7.8 \mathrm{~Hz}), 7.62(\mathrm{dt}, 1 \mathrm{H}, J=7.8$ and $1.2 \mathrm{~Hz})$, and $8.11(\mathrm{~d}, 1 \mathrm{H}, J=7.8 \mathrm{~Hz})$; ${ }^{13} \mathrm{C}-$ NMR $\left(\mathrm{CDCl}_{3}, 150 \mathrm{MHz}\right) \delta 32.9,50.4,53.5,83.5,125.8,125.9,127.9,128.6,128.7,133.4$, 136.7, 147.1, 163.7, 170.7, and 188.7; Anal. Calcd for $\mathrm{C}_{16} \mathrm{H}_{15} \mathrm{NO}_{5}$ : C, 63.78; H, 5.02; N, 4.65. Found: C, 63.22; H, 4.98; N, 4.57.

\section{5-Benzyl-2,4a-Epoxy-6-oxo-2,4a,5,6-tetrahydro-1H-phenanthridine-10b-carboxylic Acid Methyl Ester (25)}

To a solution containing $4.0 \mathrm{~g}(9.9 \mathrm{mmol})$ of $N$-benzyl- $N$-furan-2-yl-2-iodo-benzamide 47 and $5.2 \mathrm{~g}$ (14 mmol) of methyl 2-tri- $n$-butyl stannylacrylate 28 in $40 \mathrm{~mL}$ of DMF under argon atmosphere was added $1.2 \mathrm{~g}(0.99 \mathrm{mmol})$ of $\mathrm{Pd}\left(\mathrm{PPh}_{3}\right)_{4}$ and $0.57 \mathrm{~g}(3.0 \mathrm{mmol})$ of $\mathrm{Cul}$. The reaction mixture was stirred at $\mathrm{rt}$ for $20 \mathrm{~min}$, followed by the addition of $2.3 \mathrm{~g}(15 \mathrm{mmol})$ of $\mathrm{CsF}$. After stirring at $\mathrm{rt}$ for $30 \mathrm{~min}$, the reaction mixture was heated at $55^{\circ} \mathrm{C}$ for $8 \mathrm{~h}$. The mixture 
was cooled to rt, diluted with EtOAc and $\mathrm{H}_{2} \mathrm{O}$, and filtered over a pad of Celite. The organic layer was separated and the aqueous layer was extracted with EtOAc. The combined organic layers were washed with $\mathrm{H}_{2} \mathrm{O}$, brine, and dried over $\mathrm{MgSO}_{4}$. After removing the solvent under reduced pressure, the residue was subjected to flash silica gel chromatography to give $1.9 \mathrm{~g}$ (55\%) of cycloadduct 25 as white solid; mp 183.5-185 ${ }^{\circ} \mathrm{C}$; IR (neat) 1736, 1664, 1398, 1347, and $1257 \mathrm{~cm}^{-1 ; 1} \mathrm{H}-\mathrm{NMR}\left(\mathrm{CDCl}_{3}, 600 \mathrm{MHz}\right) \delta 2.60(\mathrm{dd}, 1 \mathrm{H}, J=11.4$ and $4.8 \mathrm{~Hz}), 2.84(\mathrm{~d}, 1 \mathrm{H}$, $J=11.4 \mathrm{~Hz}), 3.45(\mathrm{~s}, 3 \mathrm{H}), 4.39(\mathrm{~d}, 1 \mathrm{H}, J=15.6 \mathrm{~Hz}), 4.89(\mathrm{dd}, 1 \mathrm{H}, J=4.8$ and $1.8 \mathrm{~Hz}), 5.58(\mathrm{~d}$, $1 \mathrm{H}, J=15.6 \mathrm{~Hz}), 6.13(\mathrm{~d}, 1 \mathrm{H}, J=5.4 \mathrm{~Hz}), 6.56(\mathrm{dd}, 1 \mathrm{H}, J=5.4$ and $1.8 \mathrm{~Hz}), 7.25(\mathrm{t}, 1 \mathrm{H}, J=7.2$ $\mathrm{Hz}), 7.32-7.44(\mathrm{~m}, 6 \mathrm{H}), 7.52(\mathrm{dt}, 1 \mathrm{H}, J=7.2$ and $1.8 \mathrm{~Hz})$, and $8.27(\mathrm{dd}, 1 \mathrm{H}, J=7.2$ and 1.8 $\mathrm{Hz}) ;{ }^{13} \mathrm{C}-\mathrm{NMR}\left(\mathrm{CDCl}_{3}, 150 \mathrm{MHz}\right) \delta 42.0,49.0,52.6,54.2,74.6,100.5,126.9,127.1,127.3$, 128.2, 128.3 128.6, 129.5, 133.0, 133.1, 138.6, 139.3, 139.6, 164.4, and 171.4; Anal. Calcd for $\mathrm{C}_{22} \mathrm{H}_{19} \mathrm{NO}_{4}$ : C, 73.12; H, 5.30; N, 3.88. Found: C, 73.19; H, 5.22; N, 3.91.

\section{5-Benzyl-2,4a-epoxy-3,4-dihydroxy-I-6-oxo-2,4a,5,6-tetrahydro-1 H-phenanthridine-10b- carboxylic Acid Methyl Ester (26)}

To a solution containing $1.0 \mathrm{~g}(2.8 \mathrm{mmol})$ of cycloadduct 25 in $40 \mathrm{~mL}$ of acetone and $4 \mathrm{~mL}$ of $\mathrm{H}_{2} \mathrm{O}$ at $\mathrm{rt}$ was added $0.54 \mathrm{~g}(4.6 \mathrm{mmol})$ of NMO $(N$-methyl morpholine $N$-oxide $)$ and catalytic $\mathrm{OsO}_{4}$. The mixture was stirred at $\mathrm{rt}$ for $12 \mathrm{~h}$, diluted with $\mathrm{H}_{2} \mathrm{O}$, and extracted with $\mathrm{CH}_{2} \mathrm{Cl}_{2}$. The organic extracts were washed with $\mathrm{H}_{2} \mathrm{O}$, brine, and dried over $\mathrm{MgSO}_{4}$. Concentration under reduced pressure furnished diol $\mathbf{2 6}$ as a white solid in $98 \%$ yield; IR (neat) 3384,1733 , 1654 , and $1242 \mathrm{~cm}^{-1 ; 1} \mathrm{H}-\mathrm{NMR}\left(\mathrm{CDCl}_{3}, 400 \mathrm{MHz}\right) \delta 2.40(\mathrm{dd}, 1 \mathrm{H}, J=12.8$ and $6.4 \mathrm{~Hz}), 3.01$ $(\mathrm{d}, 1 \mathrm{H}, J=12.8 \mathrm{~Hz}), 3.15(\mathrm{~d}, 1 \mathrm{H}, J=6.0 \mathrm{~Hz}), 3.33(\mathrm{~d}, 1 \mathrm{H}, J=5.6 \mathrm{~Hz}), 3.63(\mathrm{~s}, 3 \mathrm{H}), 3.95(\mathrm{t}, 1 \mathrm{H}$, $J=6.0 \mathrm{~Hz}), 4.04(\mathrm{t}, 1 \mathrm{H}, J=5.6 \mathrm{~Hz}), 4.27(\mathrm{~d}, 1 \mathrm{H}, J=6.4 \mathrm{~Hz}), 5.21(\mathrm{~d}, 1 \mathrm{H}, J=16.0 \mathrm{~Hz}), 5.45(\mathrm{~d}$, $1 \mathrm{H}, J=16.0 \mathrm{~Hz}), 7.17(\mathrm{~d}, 1 \mathrm{H}, \mathrm{J}=7.6 \mathrm{~Hz}), 7.18-7.23(\mathrm{~m}, 1 \mathrm{H}), 7.29-7.35(\mathrm{~m}, 4 \mathrm{H}), 7.40(\mathrm{dt}, 1 \mathrm{H}$, $J=7.6$ and $0.8 \mathrm{~Hz}), 7.53(\mathrm{dt}, 1 \mathrm{H}, J=7.6$ and $1.2 \mathrm{~Hz})$, and $8.18(\mathrm{dd}, 1 \mathrm{H}, J=8.0$ and 1.2 $\mathrm{Hz}) ;{ }^{13} \mathrm{C}-\mathrm{NMR}\left(\mathrm{CDCl}_{3}, 150 \mathrm{MHz}\right) \delta 39.2,48.6,53.4,55.6,73.0,73.5,77.2,96.5,126.0,126.1$, $126.2,126.6,128.3,128.7,129.3,133.6,139.5,140.3,165.8$, and 171.6.

\section{5-Benzyl-2,3,4-trihydroxy-6-oxo-2,3,4,4a,5,6-hexahydro-1H-phenanthridine-10b-carboxylic Acid Methyl Ester (27)}

To a suspension containing $1.8 \mathrm{~g}(0.49 \mathrm{mmol})$ of diol 26 in $100 \mathrm{~mL}$ of $\mathrm{CH}_{2} \mathrm{Cl}_{2}$ at $-78{ }^{\circ} \mathrm{C}$ was added $7.8 \mathrm{~mL}(4.9 \mathrm{mmol})$ of $\mathrm{Et}_{3} \mathrm{SiH}$, followed by the slow addition of $3.1 \mathrm{~mL}(2.5 \mathrm{mmol})$ of $\mathrm{BF}_{3} \cdot \mathrm{Et}_{2} \mathrm{O}$. After stirring for $1 \mathrm{~h}$, the reaction mixture was allowed to warm to $\mathrm{rt}$ and was stirred until the color of the reaction mixture turned into green ( $c$ a $20 \mathrm{~min}$ ). The reaction mixture was quenched with a saturated $\mathrm{NH}_{4} \mathrm{Cl}$ solution and extracted with $\mathrm{CHCl}_{3}$. The combined organic extracts were dried over $\mathrm{MgSO}_{4}$ and concentrated under reduced pressure. The residue was subjected to flash silica gel chromatography to give $1.26 \mathrm{~g} \mathrm{(74 \% )}$ of triol 27 as a clear oil; IR (neat) 3383,1729 , and $1634 \mathrm{~cm}^{-1} ; 1 \mathrm{H}-\mathrm{NMR}\left(\mathrm{CDCl}_{3}, 400 \mathrm{MHz}\right) \delta 2.16(\mathrm{t}, 1 \mathrm{H}, J=12.8 \mathrm{~Hz})$, $2.62(\mathrm{dd}, 1 \mathrm{H}, J=12.8$ and $4.0 \mathrm{~Hz}), 3.43(\mathrm{~s}, 3 \mathrm{H}), 3.98-4.03(\mathrm{~m}, 1 \mathrm{H}), 4.09(\mathrm{~d}, 1 \mathrm{H}, J=10.4 \mathrm{~Hz})$, $4.15(\mathrm{t}, 1 \mathrm{H}, J=2.8 \mathrm{~Hz}), 4.72(\mathrm{dd}, 1 \mathrm{H}, J=10.4$ and $3.6 \mathrm{~Hz}), 4.95(\mathrm{~d}, 1 \mathrm{H}, J=16.0 \mathrm{~Hz}), 5.25(\mathrm{~d}$, $1 \mathrm{H}, J=16.0 \mathrm{~Hz}), 7.19-7.40(\mathrm{~m}, 7 \mathrm{H}), 7.55(\mathrm{dt}, 1 \mathrm{H}, J=7.6$ and $1.2 \mathrm{~Hz})$, and $8.09(\mathrm{dd}, 1 \mathrm{H}, J=$ 7.6 and $1.2 \mathrm{~Hz}) ;{ }^{13} \mathrm{C}-\mathrm{NMR}\left(\mathrm{CDCl}_{3}, 100 \mathrm{MHz}\right) \delta 33.4,47.5,50.4,52.9,62.4,66.9,67.8,72.8$, $124.6,126.8,127.0,128.4,128.5,128.9,129.1,132.6,139.5,141.2,166.8$, and 172.2; HRMS Calcd for $\left[\left(\mathrm{C}_{22} \mathrm{H}_{23} \mathrm{NO}_{6}\right)+\mathrm{H}\right]^{+} 398.1598$. Found: 398.1594 .

12-Acetoxy-7-benzyl-16,16-dimethyl-6-oxo-7,8,11,12,13,14-hexahydro-6H-15,17-dioxa-7-azacyclopenta[a]phenanthrene-9-carboxylic Acid Methyl Ester (28)

To a solution containing $0.90 \mathrm{~g}(2.3 \mathrm{mmol})$ of triol 27 in $20 \mathrm{~mL} \mathrm{CH}_{2} \mathrm{Cl}_{2}$ at $0{ }^{\circ} \mathrm{C}$ was added 0.9 $\mathrm{mL}(12 \mathrm{mmol})$ of pyridine, followed by the addition of $0.17 \mathrm{~mL}(2.4 \mathrm{mmol})$ of acetyl chloride in $2 \mathrm{~mL}$ of $\mathrm{CH}_{2} \mathrm{Cl}_{2}$ The reaction mixture was stirred at $0{ }^{\circ} \mathrm{C}$ for $20 \mathrm{~min}$, quenched with a saturated $\mathrm{NaHCO}_{3}$ solution and extracted with $\mathrm{CHCl}_{3}$. The organic extracts were dried over 
$\mathrm{MgSO}_{4}$ and concentrated under reduced pressure. The residue was taken up in $10 \mathrm{~mL}$ of THF and was concentrated under reduced pressure in order to completely remove pyridine. The residue was dissolved in $3 \mathrm{~mL}$ of DMF, followed by the addition of $1.0 \mathrm{~mL}$ of 2,2dimethoxypropane and a catalytic amount of $p$-toluene sulfonic acid was added. The reaction mixture was stirred at $\mathrm{rt}$ for $12 \mathrm{~h}$, quenched with a saturated $\mathrm{NaHCO}_{3}$ solution and extracted with EtOAc. The combined organic layers were washed with $\mathrm{H}_{2} \mathrm{O}$, brine and dried over $\mathrm{MgSO}_{4}$. After removing the solvent under reduced pressure, the residue was subjected to flash silica gel chromatography to give $0.78 \mathrm{~g}(71 \%)$ of ketal $\mathbf{2 8}$ as a white solid: mp 206.5-207.5 ${ }^{\circ} \mathrm{C}$; IR (neat) $1739,1654,1239$, and $1060 \mathrm{~cm}^{-1 ;}{ }_{1}^{1} \mathrm{H}-\mathrm{NMR}\left(\mathrm{CDCl}_{3}, 400 \mathrm{MHz}\right) \delta 1.37(\mathrm{~s}, 3 \mathrm{H})$, $1.40(\mathrm{~s}, 3 \mathrm{H}), 2.14(\mathrm{~s}, 3 \mathrm{H}), 2.22(\mathrm{dd}, 1 \mathrm{H}, J=13.2$ and $12.0 \mathrm{~Hz}), 2.79(\mathrm{dd}, 1 \mathrm{H}, J=13.2$ and 4.8 $\mathrm{Hz}), 3.34(\mathrm{~s}, 3 \mathrm{H}), 4.04(\mathrm{~d}, 1 \mathrm{H}, J=8.8 \mathrm{~Hz}), 4.55(\mathrm{t}, 1 \mathrm{H}, J=4.4 \mathrm{~Hz}), 4.89(\mathrm{~d}, 1 \mathrm{H}, J=15.6 \mathrm{~Hz})$, $4.95(\mathrm{dd}, 1 \mathrm{H}, J=8.8$ and $5.2 \mathrm{~Hz}), 5.26(\mathrm{dt}, 1 \mathrm{H}, J=12.0$ and $4.4 \mathrm{~Hz}), 5.44(\mathrm{~d}, 1 \mathrm{H}, J=15.6 \mathrm{~Hz})$, $7.19-7.41(\mathrm{~m}, 6 \mathrm{H}), 7.48(\mathrm{dt}, 1 \mathrm{H}, J=7.6$ and $1.2 \mathrm{~Hz}), 7.56(\mathrm{dt}, 1 \mathrm{H}, J=7.6$ and $1.6 \mathrm{~Hz})$, and $8.19(\mathrm{dd}, 1 \mathrm{H}, J=7.6$ and $1.6 \mathrm{~Hz}) ;{ }^{13} \mathrm{C}-\mathrm{NMR}\left(\mathrm{CDCl}_{3}, 100 \mathrm{MHz}\right) \delta 21.4,26.6,28.5,31.4,46.5$, 50.6, 53.0, 63.6, 67.4, 74.0, 75.0, 110.5, 124.6, 126.9, 128.0, 128.4, 128.6, 129.0, 129.3, 132.6, 139.4, 140.0, 166.0, 170.4, and 171.6; Anal. Calcd for $\mathrm{C}_{27} \mathrm{H}_{29} \mathrm{NO}_{7}$ : C, 67.63; H, 6.10; N, 2.92 . Found: C, 67.50; H, 6.17; N, 2.88 .

\section{7-Benzyl-16,16-dimethyl-6-oxo-7,8,13,14-hexahydro-6H-15,17-dioxa-7-aza-cyclopenta[a] phenanthrene-9-carboxylic Acid Methyl Ester (29)}

To a solution of $0.70 \mathrm{~g}(1.5 \mathrm{mmol})$ of ketal 28 in $10 \mathrm{~mL}$ of THF at rt was added $0.22 \mathrm{~g}$ (3.8 $\mathrm{mmol}$ ) of $\mathrm{NaOMe}$ in several portions. After stirring for $20 \mathrm{~min}$, the mixture was quenched with a saturated $\mathrm{NH}_{4} \mathrm{Cl}$ solution, and extracted with EtOAc. The organic extracts were washed with $\mathrm{H}_{2} \mathrm{O}$, brine, and dried over $\mathrm{MgSO}_{4}$. Concentration under reduced pressure gave the corresponding alcohol derived from acetate hydrolysis in quantitative yield which was used in the next step without further purification; ${ }^{1} \mathrm{H}-\mathrm{NMR}\left(\mathrm{CDCl}_{3}, 400 \mathrm{MHz}\right) \delta 2.08(\mathrm{dd}, 1 \mathrm{H}, J=$ 13.4 and $10.4 \mathrm{~Hz}$ ), 2.38 (brs, $1 \mathrm{H}), 2.84(\mathrm{dd}, 1 \mathrm{H}, J=13.4$ and $5.2 \mathrm{~Hz}), 3.31(\mathrm{~s}, 3 \mathrm{H}), 4.02-4.12$ $(\mathrm{m}, 2 \mathrm{H}), 4.49(\mathrm{t}, 1 \mathrm{H}, J=5.6 \mathrm{~Hz}), 4.87(\mathrm{~d}, 1 \mathrm{H}, J=15.6 \mathrm{~Hz}), 4.89(\mathrm{dd}, 1 \mathrm{H}, J=8.8$ and $5.6 \mathrm{~Hz})$, $5.46(\mathrm{~d}, 1 \mathrm{H}, J=15.6 \mathrm{~Hz}), 7.19-7.32(\mathrm{~m}, 5 \mathrm{H}), 7.43(\mathrm{~d}, 1 \mathrm{H}, J=7.6 \mathrm{~Hz}), 7.47(\mathrm{t}, 1 \mathrm{H}, J=7.6 \mathrm{~Hz})$, $7.56(\mathrm{td}, 1 \mathrm{H}, J=7.6$ and $1.4 \mathrm{~Hz})$, and $8.18(\mathrm{dd}, 1 \mathrm{H}, J=7.6$ and $1.4 \mathrm{~Hz})$.

To a solution containing $0.45 \mathrm{~g}(1.0 \mathrm{mmol})$ of the above alcohol in $18 \mathrm{~mL}$ of THF was added $0.08 \mathrm{~g}(2.1 \mathrm{mmol})$ of $\mathrm{NaH}\left(60 \%\right.$ dispersion in mineral) at $0{ }^{\circ} \mathrm{C}$. After stirring for $10 \mathrm{~min}$, the mixture was warmed to $\mathrm{rt}$ and was stirred for an additional $30 \mathrm{~min}$. The mixture was cooled to $0{ }^{\circ} \mathrm{C}$, and $0.25 \mathrm{~mL}(4.2 \mathrm{mmol})$ of $\mathrm{CS}_{2}$ was added. The solution was stirred for $1 \mathrm{~h}$ at this temperature and then $0.5 \mathrm{~mL}(8.3 \mathrm{mmol})$ of methyl iodide was added. After stirring for $10 \mathrm{~min}$, the mixture was warmed to $\mathrm{rt}$ and was stirred for an additional $30 \mathrm{~min}$. The solution was quenched with a saturated $\mathrm{NH}_{4} \mathrm{Cl}$ solution and extracted with EtOAc. The combined organic extracts were washed with $\mathrm{H}_{2} \mathrm{O}$ and brine, and dried over $\mathrm{MgSO}_{4}$. After concentration under reduced pressure, the residue was taken up in $20 \mathrm{~mL}$ of 1,2-dichlorobenzene and was heated at reflux for $12 \mathrm{~h}$. After cooling to room temperature, the mixture was subjected to flash silica gel chromatography to give $0.4 \mathrm{~g}$ (92\%) of alkene $\mathbf{2 9}$ as a pale yellow oil; IR (neat) 1734,1654, and $1210 \mathrm{~cm}^{-1 ;}{ }_{1} \mathrm{H}-\mathrm{NMR}\left(\mathrm{CDCl}_{3}, 600 \mathrm{MHz}\right) \delta 1.41(\mathrm{~s}, 3 \mathrm{H}), 1.43(\mathrm{~s}, 3 \mathrm{H}), 3.24(\mathrm{~s}, 3 \mathrm{H}), 3.97$

$(\mathrm{d}, 1 \mathrm{H}, J=9.0 \mathrm{~Hz}), 4.79(\mathrm{~d}, 1 \mathrm{H}, J=15.6 \mathrm{~Hz}), 4.81-4.83(\mathrm{~m}, 1 \mathrm{H}), 4.50(\mathrm{t}, 1 \mathrm{H}, J=8.4 \mathrm{~Hz}), 5.58$ $(\mathrm{d}, 1 \mathrm{H}, J=15.6 \mathrm{~Hz}), 6.20(\mathrm{dd}, 1 \mathrm{H}, J=10.2$ and $3.0 \mathrm{~Hz}), 6.43(\mathrm{~d}, 1 \mathrm{H}, J=10.2 \mathrm{~Hz}), 7.21(\mathrm{t}, 1 \mathrm{H}$, $J=7.2 \mathrm{~Hz}), 7.25-7.33(\mathrm{~m}, 4 \mathrm{H}), 7.47-7.50(\mathrm{~m}, 2 \mathrm{H}), 7.57(\mathrm{t}, 1 \mathrm{H}, J=7.2 \mathrm{~Hz})$, and $8.22(\mathrm{~d}, 1 \mathrm{H}$, $J=7.8 \mathrm{~Hz}) ;{ }^{13} \mathrm{C}-\mathrm{NMR}\left(\mathrm{CDCl}_{3}, 150 \mathrm{MHz}\right) \delta 24.8,27.4,46.3,52.6,53.1,64.2,72.2,73.0,109.4$, $124.4,126.5,127.0,127.8,28.5,128.6,129.8,129.9,130.0,132.3,138.1,140.4,166.5$, and 170.7; HRMS Calcd for $\left[\left(\mathrm{C}_{25} \mathrm{H}_{25} \mathrm{NO}_{5}\right)+\mathrm{H}\right]^{+}: 420.1806$. Found: 420.1804 . 


\section{7-Benzyl-12-hydroxy-16,16-dimethyl-8,12,13,14-tetrahydro-7H-15,17-dioxa-7-aza-cyclopenta [a]phenanthren-6-one (35)}

To a solution of $0.30 \mathrm{~g}(0.7 \mathrm{mmol})$ of ketal $29 \mathrm{in} 15 \mathrm{~mL}$ of acetone and $1.5 \mathrm{~mL}$ of $\mathrm{H}_{2} \mathrm{O}$ was added $0.12 \mathrm{~g}(1.0 \mathrm{mmol})$ of NMO ( $\mathrm{N}$-methyl morpholine- $\mathrm{N}$-oxide) and catalytic $\mathrm{OsO}_{4}$. The mixture was stirred at $\mathrm{rt}$ for $12 \mathrm{~h}$, quenched with a saturated $\mathrm{Na}_{2} \mathrm{~S}_{2} \mathrm{O}_{3}$ solution, and extracted with EtOAc. The combined organic layers were washed with $\mathrm{H}_{2} \mathrm{O}$ and brine, dried over $\mathrm{MgSO}_{4}$, and concentrated under reduced pressure. To the residue was added $20 \mathrm{~mL}$ of THF, $0.5 \mathrm{~mL}$ ( $3.5 \mathrm{mmol})$ of $\mathrm{Et}_{3} \mathrm{~N}$, and $0.14 \mathrm{~mL}(1.8 \mathrm{mmol})$ of mesyl chloride. The mixture was stirred at room temperature for $12 \mathrm{~h}$, quenched with a saturated $\mathrm{NaHCO}_{3}$ solution, and extracted with EtOAc. The organic extracts were washed with $\mathrm{H}_{2} \mathrm{O}$, brine and dried over $\mathrm{MgSO}_{4}$. After concentration under reduced pressure, the residue was subjected to flash silica gel chromatography to give $0.26 \mathrm{~g}(74 \%)$ of mesylate 32 as a white solid; $\mathrm{mp} 231-232{ }^{\circ} \mathrm{C}$; IR (neat) $1793,1653,1361$, and $1182 \mathrm{~cm}^{-1 ; 1} \mathrm{H}-\mathrm{NMR}\left(\mathrm{CDCl}_{3}, 400 \mathrm{MHz}\right) \delta 1.35(\mathrm{~s}, 3 \mathrm{H}), 1.51(\mathrm{~s}$, $3 \mathrm{H}), 3.23(\mathrm{~s}, 3 \mathrm{H}), 4.32(\mathrm{~d}, 1 \mathrm{H}, J=5.2 \mathrm{~Hz}), 4.48-4.54(\mathrm{~m}, 2 \mathrm{H}), 4.70(\mathrm{~d}, 1 \mathrm{H}, J=16.8 \mathrm{~Hz}), 5.16$ $(\mathrm{d}, 1 \mathrm{H}, J=3.6 \mathrm{~Hz}), 5.44(\mathrm{~d}, 1 \mathrm{H}, J=16.8 \mathrm{~Hz}), 5.71(\mathrm{~s}, 1 \mathrm{H}), 7.20-7.32(\mathrm{~m}, 5 \mathrm{H}), 7.54-7.58(\mathrm{~m}$, $2 \mathrm{H}), 7.80-7.91(\mathrm{~m}, 1 \mathrm{H})$, and $8.33-8.36(\mathrm{~m}, 1 \mathrm{H}) ;{ }^{13} \mathrm{C}-\mathrm{NMR}\left(\mathrm{CDCl}_{3}, 150 \mathrm{MHz}\right) \delta 25.6,27.7$, 39.7, 47.1, 50.7, 65.9, 73.2, 74.5, 79.4, 81.1, 113.1, 126.4, 126.5, 127.2, 128.9, 129.7, 130.1, 130.2, 131.2, 132.8, 138.6, 165.2, and 170.1; Anal. Calcd for $\mathrm{C}_{25} \mathrm{H}_{25} \mathrm{NO}_{8} \mathrm{~S}: \mathrm{C}, 60.11 ; \mathrm{H}, 5.04$; N, 2.80. Found: C, 59.87; H, 4.99; N, 2.85 .

To a solution of $0.15 \mathrm{~g}(0.3 \mathrm{mmol})$ of the above mesylate 32 in $6 \mathrm{~mL}$ of THF was added a solution of $0.05 \mathrm{~g}(1.2 \mathrm{mmol})$ of $\mathrm{LiOH}$ in $1 \mathrm{~mL}$ of $\mathrm{H}_{2} \mathrm{O}$. The mixture was stirred at $\mathrm{rt}$ for 20 min and then heated at $60{ }^{\circ} \mathrm{C}$ for $10 \mathrm{~min}$. After cooling to room temperature, the mixture was diluted with a saturated $\mathrm{NH}_{4} \mathrm{Cl}$ solution and EtOAc. The organic extracts was washed with $\mathrm{H}_{2} \mathrm{O}$, brine, and dried over $\mathrm{MgSO}_{4}$. Concentration under reduced pressure afforded $0.1 \mathrm{~g}(90 \%)$ of alcohol 35 as a white solid; mp 246-247 ${ }^{\circ} \mathrm{C}$; IR (neat) 33982 and $1627 \mathrm{~cm}^{-1 ;}{ }^{\mathrm{H}-\mathrm{NMR}}$ $\left(\mathrm{CDCl}_{3}, 400 \mathrm{MHz}\right) \delta 1.28(\mathrm{~s}, 3 \mathrm{H}), 1.56(\mathrm{~s}, 3 \mathrm{H}), 2.65$ (brs, $\left.1 \mathrm{H}\right), 3.95(\mathrm{t}, 1 \mathrm{H}, J=7.6 \mathrm{~Hz}), 4.23$ $(\mathrm{dt}, 1 \mathrm{H}, J=8.0$ and $2.4 \mathrm{~Hz}), 4.28-4.36(\mathrm{~m}, 2 \mathrm{H}), 4.87(\mathrm{~d}, 1 \mathrm{H}, J=14.8 \mathrm{~Hz}), 5.56(\mathrm{~d}, 1 \mathrm{H}, J=$ $14.8 \mathrm{~Hz}), 6.55(\mathrm{t}, 1 \mathrm{H}, J=2.8 \mathrm{~Hz}), 7.19-7.35(\mathrm{~m}, 5 \mathrm{H}), 7.39(\mathrm{dt}, 1 \mathrm{H}, J=7.6$ and $1.2 \mathrm{~Hz}), 7.48$ (dt, $J=7.6$ and $1.2 \mathrm{~Hz})$, and $8.30(\mathrm{dd}, 1 \mathrm{H}, J=7.6$ and $1.2 \mathrm{~Hz}) ;{ }^{13} \mathrm{C}-\mathrm{NMR}\left(\mathrm{CDCl}_{3}, 150 \mathrm{MHz}\right)$ $\delta 24.7,27.3,47.8,59.7,72.6,79.8,79.9,111.7,121.7,125.7,126.3,127.3,128.3,128.5,128.6$, 128.9, 129.5, 131.8, 132.6, 137.8, and 162.7; Anal. Calcd for $\mathrm{C}_{23} \mathrm{H}_{23} \mathrm{NO}_{4}$ : C, 73.19; $\mathrm{H}, 6.14$; N, 3.71. Found: C, 73.20; H, 6.10; N, 3.77.

\section{6-Iodo-benzo[1,3]dioxole-5-carboxylic Acid Furan-2-yl Amide (39)}

To a solution of $4.5 \mathrm{~g}(25 \mathrm{mmol})$ of furan-2-yl-carbamic acid 2-tert-butyl ester (37a) 48 in 40 $\mathrm{mL}$ of THF at $0{ }^{\circ} \mathrm{C}$ was added $11 \mathrm{~mL}(27 \mathrm{mmol})$ of a $2.5 \mathrm{M} \mathrm{n}$-BuLi in hexane solution. The reaction mixture was stirred for $20 \mathrm{~min}$ and was then added dropwise through a cannula to a solution containing $6.4 \mathrm{~g}$ (21 mmol) of 6-iodo-benzo[1,3]-dioxole-5-carbonyl chloride (36) 49 in $40 \mathrm{~mL}$ of THF at $0^{\circ} \mathrm{C}$. The resulting solution was stirred at $0{ }^{\circ} \mathrm{C}$ for $20 \mathrm{~min}$, diluted with $200 \mathrm{~mL}$ of $\mathrm{H}_{2} \mathrm{O}$, and extracted with EtOAc. The combined extracts were washed with $\mathrm{H}_{2} \mathrm{O}$ and brine, dried over $\mathrm{MgSO}_{4}$ and concentrated under reduced pressure to afford carbamate 38 as a brown oil.

To this oil was added $50 \mathrm{~mL}$ of $\mathrm{CH}_{3} \mathrm{CN}$ and $1.9 \mathrm{~g}(6.2 \mathrm{mmol})$ of $\mathrm{Mg}\left(\mathrm{ClO}_{4}\right)_{2}$. The reaction mixture was heated to $50{ }^{\circ} \mathrm{C}$ for $1 \mathrm{~h}$, cooled to room temperature, diluted with $300 \mathrm{~mL}$ of $\mathrm{H}_{2} \mathrm{O}$, and extracted with EtOAc. The combined organic layers were washed with $\mathrm{H}_{2} \mathrm{O}$, brine and dried over $\mathrm{MgSO}_{4}$. After removing the solvent under reduced pressure, the residue was recrystallized from EtOAc to give $3.4 \mathrm{~g}(46 \%)$ of the titled compound $\mathbf{3 9}$ as a white solid. The filtrate was subjected to silica gel chromatography to give an additional $2.1 \mathrm{~g}$ for an overall yield of $75 \%$; mp $192-193{ }^{\circ} \mathrm{C}$; IR (neat) $3228,1660,1531,1476$, and $1243 \mathrm{~cm}^{-1 ; 1} \mathrm{H}-\mathrm{NMR}$ (acetone- $\left.\mathrm{d}_{6}, 600 \mathrm{MHz}\right) \delta 6.12(\mathrm{~s}, 2 \mathrm{H}), 6.40(\mathrm{~d}, 1 \mathrm{H}, J=2.4 \mathrm{~Hz}), 6.46(\mathrm{t}, 1 \mathrm{H}, J=2.4 \mathrm{~Hz}), 7.10$ 
(s, 1H), $7.23(\mathrm{dd}, 1 \mathrm{H}, J=2.4$ and $1.2 \mathrm{~Hz}), 7.36(\mathrm{~s}, 1 \mathrm{H})$, and 10.07 (brs, $1 \mathrm{H})$; ${ }^{13} \mathrm{C}-\mathrm{NMR}$ (acetone$\left.\mathrm{d}_{6}, 150 \mathrm{MHz}\right) \delta 82.5,95.5,97.8,103.5,109.6,112.2,119.8,136.4,147.5,149.2,150.7$, and 165.5; Anal. Calcd for $\mathrm{C}_{12} \mathrm{H}_{8} \mathrm{INO}_{4}$ : C, 40.36; H, 2.26; N, 3.92. Found: C, 40.51; H, 2.12; N, 3.93 .

\section{6-lodo-benzo[1,3]dioxole-5-carboxylic Acid Furan-2-yl-(4-methoxy-benzyl)-Amide (11)}

To a solution of $0.70 \mathrm{~g}(1.9 \mathrm{mmol})$ of the above amide $39 \mathrm{in} 8 \mathrm{~mL}$ of DMF at $0{ }^{\circ} \mathrm{C}$ was added $0.09 \mathrm{~g}(2.3 \mathrm{mmol})$ of $\mathrm{NaH}(60 \%$ in mineral oil $)$ in several portions. After stirring for $10 \mathrm{~min}$, the reaction mixture was warmed to room temperature and was stirred for an additional $30 \mathrm{~min}$. The reaction mixture was cooled to $0{ }^{\circ} \mathrm{C}$ and $0.4 \mathrm{~mL}(2.8 \mathrm{mmol})$ of 4-methoxybenzyl chloride was added dropwise. After stirring for $15 \mathrm{~min}$, the cooling bath was removed and the reaction mixture was stirred at room temperature for $4 \mathrm{~h}$. The mixture was quenched with $\mathrm{H}_{2} \mathrm{O}$ and extracted with EtOAc. The combined extracts were washed with $\mathrm{H}_{2} \mathrm{O}$, brine, and dried over $\mathrm{MgSO}_{4}$. After concentration under reduced pressure, the residue was subjected to silica gel chromatography to give $0.7 \mathrm{~g}(83 \%)$ of iodide 11 as a white solid: $\mathrm{mp} 119.5-120.5^{\circ} \mathrm{C}$; IR (neat) $1671,1610,1512,1478$, and $1237 \mathrm{~cm}^{-1 ; 1} \mathrm{H}-\mathrm{NMR}\left(\mathrm{CDCl}_{3}, 400 \mathrm{MHz}\right) \delta 3.79(\mathrm{~s}, 3 \mathrm{H})$, $4.90(\mathrm{~s}, 2 \mathrm{H}), 5.76(\mathrm{~d}, 1 \mathrm{H}, J=3.2 \mathrm{~Hz}), 5.91(\mathrm{~s}, 2 \mathrm{H}), 6.07(\mathrm{dd}, 1 \mathrm{H}, J=3.2$ and $2.4 \mathrm{~Hz}), 6.62(\mathrm{~s}$, $1 \mathrm{H}), 6.83(\mathrm{~d}, 2 \mathrm{H}, J=8.8 \mathrm{~Hz}), 7.08(\mathrm{~s}, 1 \mathrm{H}), 7.08-7.10(\mathrm{brm}, 1 \mathrm{H})$, and $7.29(\mathrm{~d}, 2 \mathrm{H}, J=8.8$

$\mathrm{Hz}) ;{ }^{13} \mathrm{C}-\mathrm{NMR}\left(\mathrm{CDCl}_{3}, 150 \mathrm{MHz}\right) \delta 51.1,55.4,82.2,102.0,105.8,108.0,111.1,113.9,118.7$, 128.8, 130.6, 135.7, 140.0, 147.3, 147.8, 148.7, 159.3, and 170.3; Anal. Calcd for $\mathrm{C}_{20} \mathrm{H}_{16} \mathrm{INO}_{5}$ : C,50.33; H, 3.38; N, 2.93. Found: C, 50.21; H, 3.34; N, 2.81.

\section{5-(4-Methoxy-benzyl)-2,4a-epoxy-6-oxo-2,4a,5,6-tetrahydro-1 $H$-[1,3]dioxolo-[4,5-]] phenanthridine-11b-carboxylic Acid Methyl Ester (13)}

A Schlenck tube charged with $0.3 \mathrm{~g}(6.3 \mathrm{mmol})$ of $\mathrm{LiCl}$ was dried with a flame under vacuum. Upon cooling, $0.12 \mathrm{~g}(0.10 \mathrm{mmol})$ of $\mathrm{Pd}\left(\mathrm{PPh}_{3}\right)_{4}$, and $0.5 \mathrm{~g}(0.5 \mathrm{mmol})$ of $\mathrm{CuCl}$ were added and the mixture was degassed 3 times under vacuum using an argon purge. To this mixture was added $8.4 \mathrm{~mL}$ of anhydrous DMSO, $0.5 \mathrm{~g}(1.0 \mathrm{mmol})$ of iodide 11, and $0.47 \mathrm{~g}(1.3 \mathrm{mmol})$ of methyl 2-tri- $n$-butyl stannylacrylate. 28 The resulting mixture was vigorously degassed by several freeze-thaw cycles $\left(-78^{\circ} \mathrm{C}\right.$ to $\left.25^{\circ} \mathrm{C}\right)$. After stirring at room temperature for $1 \mathrm{~h}$, the reaction mixture was heated at $60{ }^{\circ} \mathrm{C}$ for $20 \mathrm{~h}$. The mixture was then cooled to room temperature, diluted with $200 \mathrm{~mL}$ of EtOAc, $50 \mathrm{~mL}$ of a saturated $\mathrm{NaHCO}_{3}$ solution, $150 \mathrm{~mL}$ of $\mathrm{H}_{2} \mathrm{O}$, and filtered over a celite pad. The organic layer was separated, washed with $\mathrm{H}_{2} \mathrm{O}$ and brine, and dried over $\mathrm{MgSO}_{4}$. After removal of the solvent under reduced pressure, the residue was subjected to flash silica gel chromatography with a hexane/EtOAc/Et ${ }_{3} \mathrm{~N}$ mixture to give $0.37 \mathrm{~g}(82 \%)$ of $\mathbf{1 3}$ as a pale yellow oil: IR (neat) 1733, 1655,1513,1447,1383, and 1249 $\mathrm{cm}^{-1 ; 1} \mathrm{H}-\mathrm{NMR}\left(\mathrm{CDCl}_{3}, 600 \mathrm{MHz}\right) \delta 2.51(\mathrm{dd}, 1 \mathrm{H}, J=12.0$ and $4.8 \mathrm{~Hz}), 2,76(\mathrm{~d}, 1 \mathrm{H}, J=12.0$ $\mathrm{Hz}), 3.46$ (s, 3H), 3.79 (s, 3H), $4.32(\mathrm{~d}, 1 \mathrm{H}, J=15.6 \mathrm{~Hz}), 4.87(\mathrm{dd}, 1 \mathrm{H}, J=4.8$ and $1.5 \mathrm{~Hz})$, $5.43(\mathrm{~d}, 1 \mathrm{H}, J=15.6 \mathrm{~Hz}), 6.01(\mathrm{~s}, 2 \mathrm{H}), 6.14(\mathrm{~d}, 1 \mathrm{H}, J=5.4 \mathrm{~Hz}), 6.54(\mathrm{dd}, 1 \mathrm{H}, J=5.4$ and 1.5 $\mathrm{Hz}), 6.73(\mathrm{~s}, 1 \mathrm{H}), 6.85(\mathrm{~d}, 2 \mathrm{H}, J=8.4 \mathrm{~Hz}), 7.32(\mathrm{~d}, 2 \mathrm{H}, J=8.4 \mathrm{~Hz})$, and $7.67(\mathrm{~s}, 1 \mathrm{H})$; ${ }^{13} \mathrm{C}-$ $\mathrm{NMR}\left(\mathrm{CDCl}_{3}, 150 \mathrm{MHz}\right) \delta 42.1,48.4,52.7,54.3,55.4,74.4,100.5,102.1,107.7,108.9,113.9$, 121.6, 128.6, 130.7, 133.4, 134.7, 139.4, 147.9, 151.5, 158.8, 163.9, and 171.6; HRMS Calcd for $\left[\left(\mathrm{C}_{24} \mathrm{H}_{21} \mathrm{NO}_{7}\right)+\mathrm{H}\right]^{+}:$436.1391. Found: 436.1395 .

\section{4-(4-Methoxy-benzyl)-3b,12-epoxy-2,2-dimethyl-5-oxo-3a,4,5,11,12,12a- hexahydro-3bH-1,3,7,9-tetraoxa-4-aza-dicyclopenta[a, $h$ ]phenanthrene-10b-carboxylic Acid Methyl Ester (42)}

To a solution of $0.90 \mathrm{~g}(2.1 \mathrm{mmol})$ of alkene $13 \mathrm{in} 30 \mathrm{~mL}$ of $\mathrm{CH}_{3} \mathrm{CN}$ and $3 \mathrm{~mL}$ of $\mathrm{H}_{2} \mathrm{O}$ was added $0.4 \mathrm{~g}$ ( $4.4 \mathrm{mmol})$ of 4-methyl-morpholine- $\mathrm{N}$-oxide and a catalytic amount of $\mathrm{OsO}_{4}$. The reaction mixture was stirred at room temperature overnight and was then diluted with $200 \mathrm{~mL}$ of $\mathrm{H}_{2} \mathrm{O}$ and extracted with $\mathrm{CH}_{2} \mathrm{Cl}_{2}$. The organic extracts were washed with $\mathrm{H}_{2} \mathrm{O}$, brine, and 
dried over $\mathrm{MgSO}_{4}$. Removal of the solvent afforded diol 41 which was immediately taken up in $2 \mathrm{~mL}$ of DMF and $4 \mathrm{~mL}$ of 2,2-dimethoxypropane and $0.1 \mathrm{~g}(0.4 \mathrm{mmol})$ of pyridinium $p$ toluenesulfonate was added. The reaction mixture was stirred at room temperature overnight, quenched with a saturated $\mathrm{NaHCO}_{3}$ solution, and extracted with EtOAc. The organic layer was washed with $\mathrm{H}_{2} \mathrm{O}$, brine, and dried over $\mathrm{MgSO}_{4}$. After concentration under reduced pressure, the residue was subjected to flash silica gel chromatography to afford $0.9 \mathrm{~g}(80 \%)$ of $\mathbf{4 2}$ as a pale yellow oil: IR (neat) 1731,1655, 1513,1484, 1448, and $1246 \mathrm{~cm}^{-1 ; 1} \mathrm{H}-\mathrm{NMR}\left(\mathrm{CDCl}_{3}, 600\right.$ $\mathrm{MHz}) \delta 1.19(\mathrm{~s}, 3 \mathrm{H}), 1.37(\mathrm{~s}, 3 \mathrm{H}), 2.26(\mathrm{dd}, 1 \mathrm{H}, J=12.6$ and $6.0 \mathrm{~Hz}), 2.92(\mathrm{~d}, 1 \mathrm{H}, J=12.6$ $\mathrm{Hz}), 3.56$ (s, 3H), 3.77 (s, 3H), $4.14(\mathrm{~d}, 1 \mathrm{H}, J=4.8 \mathrm{~Hz}), 4.30(\mathrm{~d}, 1 \mathrm{H}, J=6.6 \mathrm{~Hz}), 4.42(\mathrm{~d}, 1 \mathrm{H}$, $J=5.4 \mathrm{~Hz}), 5.18(\mathrm{~d}, 1 \mathrm{H}, J=15.6 \mathrm{~Hz}), 5.37(\mathrm{~d}, 1 \mathrm{H}, J=15.6 \mathrm{~Hz}), 6.00(\mathrm{~s}, 2 \mathrm{H}), 6.50(\mathrm{~s}, 1 \mathrm{H})$, $6.80(\mathrm{~d}, 2 \mathrm{H}, J=8.4 \mathrm{~Hz}), 7.23(\mathrm{~d}, 2 \mathrm{H}, J=8.4 \mathrm{~Hz})$, and $7.61(\mathrm{~s}, 1 \mathrm{H}) ;{ }^{13} \mathrm{C}-\mathrm{NMR}\left(\mathrm{CDCl}_{3}, 150\right.$ $\mathrm{MHz}) \delta 25.1,25.8,39.2,46.9,53.4,54.9,55.5,74.9,80.6,82.6,96.5,102.1,105.5,108.5$, 112.6, 113.4, 120.9, 128.2, 132.2, 135.6, 147.8, 152.0, 158.1, 164.7, and 171.4; HRMS Calcd for $\left[\left(\mathrm{C}_{27} \mathrm{H}_{27} \mathrm{NO}_{9}\right)+\mathrm{H}\right]^{+}: 510.1759$. Found: 510.1756 .

\section{2-Hydroxy-4-(4-methoxy-benzyl)-2,2-dimethyl-5-oxo-3a,4,5,11,12,12a- hexahydro-3bH-1,3,7,9-tetraoxa-4-aza-dicyclopenta[a, $h]$ phenanthrene-10b-carboxylic Acid Methyl Ester (14)}

To a solution of $0.20 \mathrm{~g}(0.4 \mathrm{mmol})$ of acetonide 42 in $6 \mathrm{~mL}$ of $\mathrm{CH}_{2} \mathrm{Cl}_{2}$ at $-78{ }^{\circ} \mathrm{C}$ was added $3.1 \mathrm{~mL}(0.8 \mathrm{mmol})$ of a $0.25 \mathrm{M}$ solution of $\mathrm{Zn}\left(\mathrm{BH}_{4}\right)_{2}$ in $\mathrm{Et}_{2} \mathrm{O},{ }^{36}$ and $0.14 \mathrm{~mL}(0.8 \mathrm{mmol})$ of TMSOTf, respectively. After stirring for $20 \mathrm{~min}$ at $-78{ }^{\circ} \mathrm{C}$, the reaction mixture was allowed to warm to room temperature and was stirred for an additional $4 \mathrm{~h}$. The mixture was quenched with a saturated $\mathrm{NH}_{4} \mathrm{Cl}$ solution and the aqueous layer was extracted with $\mathrm{CH}_{2} \mathrm{Cl}_{2}$ The combined organic extracts were washed with $\mathrm{H}_{2} \mathrm{O}$, brine, and dried over $\mathrm{MgSO}_{4}$. After removing the solvent under reduced pressure, the residue was dissolved in $5 \mathrm{~mL}$ of THF, and this was followed by the addition of $0.4 \mathrm{~mL}(0.4 \mathrm{mmol})$ of TBAF (1.0 M in THF) at room temperature. After stirring for $5 \mathrm{~min}$, the mixture was diluted with a saturated $\mathrm{NH}_{4} \mathrm{Cl}$ solution and EtOAc. The organic layer was separated, and the aqueous layer was extracted with EtOAc. The combined organic extracts were washed with brine and dried over $\mathrm{MgSO}_{4}$. After concentration under reduced pressure, the residue was subjected to flash silica gel chromatography to afford $0.15 \mathrm{~g}(74 \%)$ of alcohol 14 as a white solid: mp 204.5-205.5 ${ }^{\circ}$; IR (neat) 3396, 1728,1639,1512,1456, and $1244 \mathrm{~cm}^{-1 ; 1} \mathrm{H}-\mathrm{NMR}\left(\mathrm{CDCl}_{3}, 400 \mathrm{MHz}\right) \delta 1.39$ (s, $3 \mathrm{H}), 1.43(\mathrm{~s}, 3 \mathrm{H}), 2.04(\mathrm{dd}, 1 \mathrm{H}, \mathrm{J}=13.6$ and $10.4 \mathrm{~Hz}), 2.24(\mathrm{~d}, 1 \mathrm{H}, \mathrm{J}=8.8 \mathrm{~Hz}), 2.69(\mathrm{dd}, 1 \mathrm{H}$, $\mathrm{J}=13.6$ and $5.2 \mathrm{~Hz}), 3.32(\mathrm{~s}, 3 \mathrm{H}), 3.77(\mathrm{~s}, 3 \mathrm{H}), 4.02(\mathrm{~d}, 1 \mathrm{H}, \mathrm{J}=8.8 \mathrm{~Hz}), 4.02-4.08(\mathrm{~m}, 1 \mathrm{H})$, $4.47(\mathrm{dd}, 1 \mathrm{H}, \mathrm{J}=5.2$ and $4.4 \mathrm{~Hz}), 4.73(\mathrm{~d}, 1 \mathrm{H}, \mathrm{J}=15.6 \mathrm{~Hz}), 4.88(\mathrm{dd}, 1 \mathrm{H}, \mathrm{J}=8.4$ and $5.6 \mathrm{~Hz})$, $5.37(\mathrm{~d}, 1 \mathrm{H}, \mathrm{J}=15.6 \mathrm{~Hz}), 6.03(\mathrm{~d}, 1 \mathrm{H}, \mathrm{J}=1.2 \mathrm{~Hz}), 6.04(\mathrm{~d}, 1 \mathrm{H}, \mathrm{J}=1.2 \mathrm{~Hz}), 6.80(\mathrm{~d}, 2 \mathrm{H}, \mathrm{J}=$ $8.8 \mathrm{~Hz}), 6.86(\mathrm{~s}, 1 \mathrm{H}), 7.23(\mathrm{~d}, 2 \mathrm{H}, \mathrm{J}=8.8 \mathrm{~Hz})$, and $7.59(\mathrm{~s}, 1 \mathrm{H}) ;{ }^{13} \mathrm{C}-\mathrm{NMR}\left(\mathrm{CDCl}_{3}, 100 \mathrm{MHz}\right)$ $\delta$ 26.4, 28.4, 35.4, 45.9, 50.2, 52.8, 55.4, 63.8, 65.6, 74.8, 75.9, 102.1, 105.1, 108.8, 109.9, 113.7, 123.7, 129.1,132.2,135.3,147.9, 151.3, 158.6, 165.6, and 172.; Anal. Calcd for $\mathrm{C}_{27} \mathrm{H}_{29} \mathrm{NO}_{9}$ : C, 63.4; H, 5.71; N, 2.74. Found: C, 63.0; H, 5.60; N, 2.70.

\section{4-(4-Methoxy-benzyl)-2,2-dimethyl-5-oxo-3a,4,5,12a-tetrahydro-3bH-1,3,7,9-tetraoxa-4-aza- dicyclopenta[$[a, h]$ phenanthrene-10b-carboxylic Acid Methyl Ester (43)}

To a solution of $0.40 \mathrm{~g}(0.7 \mathrm{mmol})$ of alcohol $14 \mathrm{in} 7 \mathrm{~mL}$ of THF was added $0.09 \mathrm{~g}(2.2 \mathrm{mmol})$ of $\mathrm{NaH}\left(60 \%\right.$ in mineral oil) at $0{ }^{\circ} \mathrm{C}$. After stirring for $10 \mathrm{~min}$, the mixture was warmed to room temperature and was stirred for an additional $30 \mathrm{~min}$. The solution was cooled to $0{ }^{\circ} \mathrm{C}$, and $0.26 \mathrm{~mL}$ ( $4.4 \mathrm{mmol}$ ) of $\mathrm{CS}_{2}$ was added and the mixture was stirred for $1 \mathrm{~h}$ at this temperature and then $0.5 \mathrm{~mL}$ ( $8.8 \mathrm{mmol}$ ) of Mel was added. After stirring for $10 \mathrm{~min}$, the mixture was warmed to room temperature and was stirred for an additional $20 \mathrm{~min}$. The solution was quenched with a saturated $\mathrm{NH}_{4} \mathrm{Cl}$ solution and then extracted with EtOAc. The combined organic extracts were washed with $\mathrm{H}_{2} \mathrm{O}$, brine, and dried over $\mathrm{MgSO}_{4}$. After concentration under reduced pressure, the residue was dissolved in $20 \mathrm{~mL}$ of 1,2-dichlorobenzene and was 
heated at reflux for $12 \mathrm{~h}$. After cooling to room temperature, the mixture was concentrated under reduced pressure and subjected to flash silica gel chromatography to give $0.34 \mathrm{~g} \mathrm{(94 \% )}$ of alkene $\mathbf{4 3}$ as a pale yellow oil; IR (neat) $1733,1650,1512,1275,1244,1210$ and $1037 \mathrm{~cm}^{-1 ; 1} \mathrm{H}-\mathrm{NMR}\left(\mathrm{CDCl}_{3}, 600 \mathrm{MHz}\right) \delta 1.43(\mathrm{~s}, 3 \mathrm{H}), 1.44(\mathrm{~s}, 3 \mathrm{H}), 3.25(\mathrm{~s}, 3 \mathrm{H}), 3.77(\mathrm{~s}, 3 \mathrm{H})$, $3.91(\mathrm{~d}, 1 \mathrm{H}, J=9.0 \mathrm{~Hz}), 4.68(\mathrm{~d}, 1 \mathrm{H}, J=15.6 \mathrm{~Hz}), 4.81(\mathrm{dt}, 1 \mathrm{H}, J=7.2$ and $1.8 \mathrm{~Hz}), 4.99(\mathrm{dd}$, $1 \mathrm{H}, J=9.0$ and $7.2 \mathrm{~Hz}), 5.49(\mathrm{~d}, 1 \mathrm{H}, J=15.6 \mathrm{~Hz}), 6.05(\mathrm{~s}, 2 \mathrm{H}), 6.18(\mathrm{dd}, 1 \mathrm{H}, J=9.6$, and 1.8 $\mathrm{Hz}), 6.26(\mathrm{dd}, 1 \mathrm{H}, J=9.6$ and $1.2 \mathrm{~Hz}), 6.80(\mathrm{~d}, 2 \mathrm{H}, J=9.0 \mathrm{~Hz}), 6.93(\mathrm{~s}, 1 \mathrm{H}), 7.23(\mathrm{~d}, 2 \mathrm{H}, J=$ $9.0 \mathrm{~Hz})$, and $7.64(\mathrm{~s}, 1 \mathrm{H}) ;{ }^{13} \mathrm{C}-\mathrm{NMR}\left(\mathrm{CDCl}_{3}, 150 \mathrm{MHz}\right) \delta 24.8,27.5,45.6,52.5,53.1,55.5$, 64.3, 72.2, 72.9, 102.1, 105.0, 109.4, 109.5, 113.9, 124.7, 126.6, 129.1, 130.2, 132.7, 133.8, 147.8, 151.2, 158.6, 165.9, and 170.8; HRMS Calcd for $\left[\left(\mathrm{C}_{27} \mathrm{H}_{27} \mathrm{NO}_{8}\right)+\mathrm{H}\right]^{+}: 494.1809$.

Found: 494.1805.

\section{Methanesulfonic Acid 4-(4-Methoxy-benzyl)-2,2-dimethyl-5,10b-dioxo-3a,3b,4, 5,10b, 11,12,12a-octahydro-1,3,7,9,12-pentaoxa-4-aza-dicyclopenta[a, $h$ ]phenanthren-11-yl Ester} (46)

To a solution of $0.25 \mathrm{~g}(0.5 \mathrm{mmol})$ of alkene $43 \mathrm{in} 8 \mathrm{~mL}$ of acetone and $0.8 \mathrm{~mL}$ of $\mathrm{H}_{2} \mathrm{O}$ was added $0.08 \mathrm{~g}(0.7 \mathrm{mmol})$ of 4-methylmorpholine- $N$-oxide and a catalytic amount of $\mathrm{OsO}_{4}$. The reaction mixture was stirred at room temperature for $12 \mathrm{~h}$, quenched with a saturated $\mathrm{Na}_{2} \mathrm{~S}_{2} \mathrm{O}_{3}$ solution and extracted with EtOAc. The combined organic layer was washed with $\mathrm{H}_{2} \mathrm{O}$, brine, and dried over $\mathrm{MgSO}_{4}$. After concentration under reduced pressure, the residue was dissolved in $10 \mathrm{~mL}$ of THF and a catalytic amount of $\mathrm{NaOMe}$ was added. After stirring for $20 \mathrm{~min}$, the mixture was quenched with $50 \mathrm{~mL}$ of $\mathrm{H}_{2} \mathrm{O}$ and extracted with EtOAc. The combined organic layer was dried over $\mathrm{MgSO}_{4}$, and concentrated under reduced pressure. To the resulting residue was added $20 \mathrm{~mL}$ of THF, $0.4 \mathrm{~mL}(3.1 \mathrm{mmol})$ of $\mathrm{Et}_{3} \mathrm{~N}$, and $0.12 \mathrm{~mL}(1.5$ $\mathrm{mmol}$ ) of $\mathrm{MsCl}$. The mixture was stirred at room temperature for $6 \mathrm{~h}$ and was then quenched with a saturated $\mathrm{NaHCO}_{3}$ solution and extracted with EtOAc. The organic layer was washed with $\mathrm{H}_{2} \mathrm{O}$, brine, and dried over $\mathrm{MgSO}_{4}$. After removing the solvent under reduced pressure, the residue was subjected to flash silica gel chromatography to give $0.22 \mathrm{~g} \mathrm{(76 \% )} \mathrm{of} 46$ as a white solid: $\mathrm{mp} 179-180{ }^{\circ} \mathrm{C}$; IR (neat) $1788,1653,1608,1508,1245,1179$, and 1037 $\mathrm{cm}^{-1 ; 1} \mathrm{H}-\mathrm{NMR}\left(\mathrm{CDCl}_{3}, 600 \mathrm{MHz}\right) \delta 1.35(\mathrm{~s}, 3 \mathrm{H}), 1.52(\mathrm{~s}, 3 \mathrm{H}), 3.22(\mathrm{~s}, 3 \mathrm{H}), 3.76(\mathrm{~s}, 3 \mathrm{H}), 4.27$ $(\mathrm{d}, 1 \mathrm{H}, J=5.4 \mathrm{~Hz}), 4.48-4.51(\mathrm{~m}, 2 \mathrm{H}), 4.57(\mathrm{~d}, 1 \mathrm{H}, J=16.2 \mathrm{~Hz}), 5.12(\mathrm{~d}, 1 \mathrm{H}, J=3.6 \mathrm{~Hz})$, $5.37(\mathrm{~d}, 1 \mathrm{H}, J=16.2 \mathrm{~Hz}), 5.63(\mathrm{~s}, 1 \mathrm{H}), 6.04(\mathrm{~s}, 1 \mathrm{H}), 6.06(\mathrm{~s}, 1 \mathrm{H}), 6.82(\mathrm{~d}, 2 \mathrm{H}, J=8.4 \mathrm{~Hz})$, $7.13(\mathrm{~d}, 2 \mathrm{H}, J=8.4 \mathrm{~Hz}), 7.31(\mathrm{~s}, 1 \mathrm{H})$, and $7.75(\mathrm{~s}, 1 \mathrm{H}) ;{ }^{13} \mathrm{C}-\mathrm{NMR}\left(\mathrm{CDCl}_{3}, 150 \mathrm{MHz}\right) \delta 25.7$, 27.7, 39.7, 46.3, 50.8, 5.4, 66.0, 73.2, 74.3, 79.4, 81.4, 102.4, 106.6, 109.8, 113.1, 114.3, 125.4, 126.2, 127.7, 130.7, 148.7, 151.5, 158.8, 164.6, and 170.1; Anal. Calcd for $\mathrm{C}_{27} \mathrm{H}_{27} \mathrm{NO}_{11} \mathrm{~S}: \mathrm{C}$, 56.54; H, 4.74; N, 2.44. Found: C, 56.29; H, 4.55; N, 2.18

\section{Methanesulfonic Acid 2,2-Dimethyl-5,10b-dioxo-3a,3b,4,5,10b,11,12,12a-oct anhydro-1,3,7,9,12-pentaoxa-4-aza-dicyclopenta[a, $h]$ phenanthren-11-yl Ester}

To a solution of $0.07 \mathrm{~g}(0.12 \mathrm{mmol})$ of mesylate $46 \mathrm{in} 1.0 \mathrm{~mL}$ of EtOAc was added $1.0 \mathrm{~mL}$ of $\mathrm{CH}_{3} \mathrm{COOH}$ and $0.04 \mathrm{~g}(0.24 \mathrm{mmol})$ of $\mathrm{PdCl}_{2}$ The resulting suspension was stirred under a hydrogen atmosphere ( $80 \mathrm{psi})$ overnight. The mixture was diluted with EtOAc and filtered over a celite pad. After concentration under reduced pressure, the residue was subjected to flash silica gel chromatography to give $0.04 \mathrm{~g}(65 \%)$ of the titled compound as a white solid: $\mathrm{mp}$ 240-241 ${ }^{\circ} \mathrm{C}$; IR (neat) 1793,1678, 1180 and $1035 \mathrm{~cm}^{-1 ;}{ }^{\mathrm{H}-\mathrm{NMR}}\left(\mathrm{CDCl}_{3}, 400 \mathrm{MHz}\right) \delta 1.42$ $(\mathrm{s}, 3 \mathrm{H}), 1.56(\mathrm{~s}, 3 \mathrm{H}), 3.25(\mathrm{~s}, 3 \mathrm{H}), 4.04(\mathrm{~d}, 1 \mathrm{H}, \mathrm{J}=6.8 \mathrm{~Hz}), 4.22(\mathrm{t}, 1 \mathrm{H}, \mathrm{J}=6.4 \mathrm{~Hz}), 4.73(\mathrm{dd}$, $1 \mathrm{H}, \mathrm{J}=5.6$ and $4.4 \mathrm{~Hz}), 5.24(\mathrm{~d}, 1 \mathrm{H}, \mathrm{J}=4.4 \mathrm{~Hz}), 5.59(\mathrm{~s}, 1 \mathrm{H}), 5.98(\mathrm{brs}, 1 \mathrm{H}), 6.05(\mathrm{~d}, 1 \mathrm{H}, \mathrm{J}=$ $1.2 \mathrm{~Hz}), 6.08(\mathrm{~d}, 1 \mathrm{H}, \mathrm{J}=1.2 \mathrm{~Hz}), 7.28(\mathrm{~s}, 1 \mathrm{H})$, and $7.69(\mathrm{~s}, 1 \mathrm{H}) ;{ }^{13} \mathrm{C}-\mathrm{NMR}\left(\mathrm{CDCl}_{3}, 150 \mathrm{MHz}\right)$ $\delta$ 26.0, 28.0, 39.8, 50.6, 60.1, 60.6, 73.7, 79.7, 81.8, 102.6, 107.3, 109.4, 114.3, 124.8, 127.1, 148.8, 152.0, 164.4, and 169.6; HRMS Calcd for $\left[\left(\mathrm{C}_{19} \mathrm{H}_{19} \mathrm{NO}_{10} \mathrm{~S}\right)+\mathrm{H}\right]^{+}:$454.0802. Found: 454.0803. 


\section{2-Hydroxy-2,2-dimethyl-3b,4,12,12a-tetrahydro-3aH-1,3,7,9-tetraoxa-4-aza-dicyclopenta [a,h]phenanthren-5-one (47)}

To a solution containing $5 \mathrm{mg}(0.01 \mathrm{mmol})$ of the above compound in $2 \mathrm{~mL}$ of THF was added a solution of $2 \mathrm{mg}(0.1 \mathrm{mmol})$ of $\mathrm{LiOH}$ in $0.5 \mathrm{~mL}$ of $\mathrm{H}_{2} \mathrm{O}$. The reaction mixture was stirred at room temperature for $20 \mathrm{~min}$ and then heated to $60^{\circ} \mathrm{C}$ for $10 \mathrm{~min}$. After cooling to room temperature, the mixture was diluted with a saturated $\mathrm{NH}_{4} \mathrm{Cl}$ solution and EtOAc was added. The organic layer was washed with $\mathrm{H}_{2} \mathrm{O}$, brine, and dried over $\mathrm{MgSO}_{4}$. Concentration under reduced pressure afforded $3.4 \mathrm{mg}(93 \%)$ of alcohol 47 as a white solid whose spectral properties were identical to that reported in the literature 50 : IR (neat) $3350,1653,1475,1257,1059$, and $1035 \mathrm{~cm}^{-1 ; 1} \mathrm{H}-\mathrm{NMR}\left(\mathrm{CDCl}_{3}, 600 \mathrm{MHz}\right) \delta 1.38$ (s, 3H), 1.53 (s, 3H), 1.64 (brs, $\left.1 \mathrm{H}\right), 4.13-4.15$ $(\mathrm{m}, 3 \mathrm{H}), 4.38-4.40(\mathrm{~m}, 1 \mathrm{H}), 6.03(\mathrm{~d}, 1 \mathrm{H}, \mathrm{J}=1.8 \mathrm{~Hz}), 6.04(\mathrm{~d}, 1 \mathrm{H}, \mathrm{J}=1.8 \mathrm{~Hz}), 6.25(\mathrm{brs}, 1 \mathrm{H})$, $7.04(\mathrm{~s}, 1 \mathrm{H})$, and $7.60(\mathrm{~s}, 1 \mathrm{H}) ;{ }^{13} \mathrm{C}-\mathrm{NMR}\left(\mathrm{CDCl}_{3}, 150 \mathrm{MHz}\right) 524.9,27.2,56.2,73.2,79.1$, 79.7, 101.6, 102.2, 107.9, 111.7, 121.0, 124.1, 127.8, 128.5, 148.9, 152.1, and 162.6.

\section{( \pm )-Lycoricidine (7)}

To a flask containing $3 \mathrm{mg}(0.01 \mathrm{mmol})$ of alcohol 47 at $0{ }^{\circ} \mathrm{C}$ was added $0.3 \mathrm{~mL}$ of cold $(-20$ $\left.{ }^{\circ} \mathrm{C}\right)$ TFA. After stirring for $40 \mathrm{~min}$, the solution was diluted with $2 \mathrm{~mL}$ of cold dioxane and concentrated under reduced pressure. The residue was subjected to flash silica gel chromatography to give $2.3 \mathrm{mg}(90 \%)$ of ( \pm )-lycoricidine (7) as a white solid whose spectral properties were identical to those reported in the literature ${ }^{50: 1} \mathrm{H}-\mathrm{NMR}$ (methanol- $d_{4}, 400 \mathrm{MHz}$ ) 8 3.89-3.92 (m, 2H), $4.24(\mathrm{ddd}, 1 \mathrm{H}, \mathrm{J}=4.8,2.0$, and $1.6 \mathrm{~Hz}), 4.37(\mathrm{ddd}, 1 \mathrm{H}, \mathrm{J}=8.0,2.4$, and $1.6 \mathrm{~Hz}), 6.04(\mathrm{~d}, 1 \mathrm{H}, \mathrm{J}=1.2 \mathrm{~Hz}), 6.05(\mathrm{~d}, 1 \mathrm{H}, \mathrm{J}=1.2 \mathrm{~Hz}), 6.16(\mathrm{~m}, 1 \mathrm{H}), 7.15(\mathrm{~s}, 1 \mathrm{H})$, and 7.38 (s, $1 \mathrm{H})$.

\section{2-Benzyloxy-4-(4-methoxy-benzyl)-2,2-dimethyl-5-oxo-3a,4,5,11,12,12a-hex ahydro-3bH-1,3,7,9-tetraoxa-4-aza-dicyclopenta[a, $h]$ phenanthrene-10 b-carbaldehyde (50)}

To a solution of $1.6 \mathrm{~g}(3.0 \mathrm{mmol})$ of alcohol 14 in $60 \mathrm{~mL}$ DMF at $0{ }^{\circ} \mathrm{C}$ was added $0.16 \mathrm{~g}(4.0$ $\mathrm{mmol}$ ) of $\mathrm{NaH}$ (60\% dispersion in mineral oil). After stirring for $10 \mathrm{~min}$, the reaction mixture was warmed to $\mathrm{rt}$ and was stirred for an additional $30 \mathrm{~min}$. The reaction mixture was cooled to $0{ }^{\circ} \mathrm{C}$ and $0.5 \mathrm{~mL}$ ( $\left.4.3 \mathrm{mmol}\right)$ of benzyl bromide was added dropwise. After stirring for 20 $\mathrm{min}$, the reaction mixture was warmed to $\mathrm{rt}$ and was stirred for an additional $5 \mathrm{~h}$. The mixture was quenched with a saturated $\mathrm{NH}_{4} \mathrm{Cl}$ solution and extracted with EtOAc. The combined organic layers were washed with $\mathrm{H}_{2} \mathrm{O}$, brine, and dried over $\mathrm{MgSO}_{4}$. After removal of the solvent under reduced pressure, the residue was subjected to flash silica gel chromatography to give $1.7 \mathrm{~g} \mathrm{(91 \% )} \mathrm{of} \mathrm{12-benzyloxy-4-(4-methoxy-benzyl)-2,2-dimethyl-5-oxo-3a,}$ 4,5,11,12,12a-hexahydro-3bH-1,3,-7,9-tetraoxa-4-aza-dicyclopenta[ $a, h]$ phenanthrene-10bcarboxylic acid methyl ester as a colorless oil; IR (neat) 1731, 1648, 1512, 1453, 1244, and $1035 \mathrm{~cm}^{-1 ; 1} \mathrm{H}-\mathrm{NMR}\left(\mathrm{CDCl}_{3}, 400 \mathrm{MHz}\right) \delta 1.39(\mathrm{~s}, 3 \mathrm{H}), 1.42(\mathrm{~s}, 3 \mathrm{H}), 2.09(\mathrm{t}, 1 \mathrm{H}, J=12.4 \mathrm{~Hz})$, $2.59(\mathrm{dd}, 1 \mathrm{H}, J=12.4$ and $4.4 \mathrm{~Hz}), 3.19(\mathrm{~s}, 3 \mathrm{H}), 3.70(\mathrm{dt}, 1 \mathrm{H}, J=12.4$ and $4.4 \mathrm{~Hz}), 3.76(\mathrm{~s}$, $3 \mathrm{H}), 3.93(\mathrm{~d}, 1 \mathrm{H}, J=8.8 \mathrm{~Hz}), 4.46(\mathrm{t}, 1 \mathrm{H}, J=4.4 \mathrm{~Hz}), 4.67(\mathrm{~s}, 2 \mathrm{H}), 4.78(\mathrm{~d}, 1 \mathrm{H}, J=15.6 \mathrm{~Hz})$, $4.86(\mathrm{dd}, 1 \mathrm{H}, J=8.8$ and $4.4 \mathrm{~Hz}), 5.31(\mathrm{~d}, 1 \mathrm{H}, J=15.6 \mathrm{~Hz}), 6.03(\mathrm{~d}, 1 \mathrm{H}, J=1.2 \mathrm{~Hz}), 6.04(\mathrm{~d}$, $1 \mathrm{H}, J=1.2 \mathrm{~Hz}), 6.79(\mathrm{~d}, 2 \mathrm{H}, J=8.8 \mathrm{~Hz}), 6.85(\mathrm{~s}, 1 \mathrm{H}), 7.22(\mathrm{~d}, 2 \mathrm{H}, J=8.8 \mathrm{~Hz}), 7.28-7.38(\mathrm{~m}$, $5 \mathrm{H})$, and $7.57(\mathrm{~s}, 1 \mathrm{H}) ;{ }^{13} \mathrm{C}-\mathrm{NMR}\left(\mathrm{CDCl}_{3}, 100 \mathrm{MHz}\right) \delta 26.7,28.6,32.0,45.9,50.3,52.6,55.4$, 63.9, 71.0, 71.4, 74.4, 75.0, 102.1, 105.0, 108.8, 110.2, 113.6, 123.7, 128.3, 128.4, 129.2, 132.2, 135.0, 137.7, 147.9, 151.3, 158.5, 165.5, and 171.6.

To a solution of $1.7 \mathrm{~g}(2.8 \mathrm{mmol})$ of the above benzyl ether in $30 \mathrm{~mL}$ of THF and $15 \mathrm{~mL}$ of

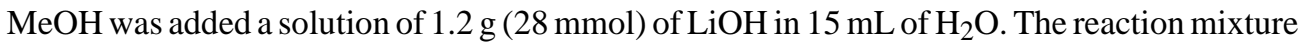
was heated at reflux for $12 \mathrm{~h}$. After cooling to rt, the mixture was acidified to $\mathrm{pH}$ of 3 with $3 \mathrm{~N} \mathrm{HCl}$ and was extracted with EtOAc. The organic extracts were dried over $\mathrm{MgSO}_{4}$ and concentrated under reduced pressure. To the residue was added $10 \mathrm{~mL}$ of $\mathrm{CH}_{2} \mathrm{Cl}_{2}$, followed by the addition of $0.4 \mathrm{~mL}(4 \mathrm{mmol})$ of $(\mathrm{COCl})_{2}$ and several drops of DMF as a catalyst. The 
resulting mixture was stirred at $\mathrm{rt}$ for $2 \mathrm{~h}$, and then concentrated under reduced pressure. The residue was taken up in $5 \mathrm{~mL}$ of $\mathrm{CH}_{2} \mathrm{Cl}_{2}$ and was concentrated under reduced pressure in order to completely remove the excess $\mathrm{HCl}$ and oxalyl chloride. The residue was taken up in $15 \mathrm{~mL}$ of $\mathrm{CH}_{2} \mathrm{Cl}_{2}$, cooled to $0{ }^{\circ} \mathrm{C}$, and then $22 \mathrm{~mL}(5.6 \mathrm{mmol})$ of $\mathrm{Zn}\left(\mathrm{BH}_{4}\right)_{2}\left(0.25 \mathrm{M} \mathrm{in} \mathrm{Et}_{2} \mathrm{O}\right)$ was added. After stirring for $20 \mathrm{~min}$, the reaction mixture was warmed to rt and was stirred for an additional $6 \mathrm{~h}$. The solution was quenched with a saturated $\mathrm{NH}_{4} \mathrm{Cl}$ solution, and extracted with $\mathrm{CH}_{2} \mathrm{Cl}_{2}$. The combined organic extracts were washed with brine, dried over $\mathrm{MgSO}_{4}$, and concentrated under reduced pressure to $50 \mathrm{~mL}$. To this crude solution was added $1.4 \mathrm{~g} 4 \AA$ molecular sieves and $0.5 \mathrm{~g}(4.2 \mathrm{mmol})$ of NMO ( $N$-methyl morpholine- $N$-oxide), followed by the addition of $0.05 \mathrm{~g}(0.14 \mathrm{mmol})$ of TPAP in several portions. The mixture was stirred at $\mathrm{rt}$ for $3 \mathrm{~h}$, and filtered through a pad of celite. The filtrate was concentrated under reduced pressure and the residue was subjected to flash silica gel chromatography to give $1.2 \mathrm{~g}(77 \%)$ of aldehyde $\mathbf{5 0}$ as a pale yellow oil; IR(neat) 1719, 1648, 1610, 1511, 1453, 1269, 1245, and $1036 \mathrm{~cm}^{-1 ;}{ }_{\mathrm{H}-\mathrm{NMR}}\left(\mathrm{CDCl}_{3}, 600 \mathrm{MHz}\right) \delta 1.35(\mathrm{~s}, 3 \mathrm{H}), 1.45(\mathrm{~s}, 3 \mathrm{H}), 1.98(\mathrm{dd}, 1 \mathrm{H}, J=12.6$ and $10.8 \mathrm{~Hz}), 2.69(\mathrm{dd}, 1 \mathrm{H}, J=12.6$ and $5.4 \mathrm{~Hz}), 3.73-3.76(\mathrm{~m}, 1 \mathrm{H}), 3.77(\mathrm{~s}, 3 \mathrm{H}), 4.25-4.27$ $(\mathrm{m}, 2 \mathrm{H}), 4.49(\mathrm{dd}, 1 \mathrm{H}, J=9.0$ and $5.4 \mathrm{~Hz}), 4.65(\mathrm{~d}, 1 \mathrm{H}, J=12.0 \mathrm{~Hz}), 4.68(\mathrm{~d}, 1 \mathrm{H}, J=12.0$ $\mathrm{Hz}), 4.79(\mathrm{~d}, 1 \mathrm{H}, J=15.6 \mathrm{~Hz}), 5.44(\mathrm{~d}, 1 \mathrm{H}, J=15.6 \mathrm{~Hz}), 6.04(\mathrm{~d}, 1 \mathrm{H}, J=0.9 \mathrm{~Hz}) 6.06(\mathrm{~d}, 1 \mathrm{H}$, $J=0.9 \mathrm{~Hz}), 6.70(\mathrm{~s}, 1 \mathrm{H}), 6.81(\mathrm{~d}, 2 \mathrm{H}, J=8.7 \mathrm{~Hz}), 7.22(\mathrm{~d}, 2 \mathrm{H}, J=8.7 \mathrm{~Hz}), 7.29-7.36(\mathrm{~m}, 5 \mathrm{H})$, $7.68(\mathrm{~s}, 1 \mathrm{H}), 9.40(\mathrm{~s}, 1 \mathrm{H}) ;{ }^{13} \mathrm{C}-\mathrm{NMR}\left(\mathrm{CDCl}_{3}, 100 \mathrm{MHz}\right) \delta 26.4,28.3,29.1,45.9,52.9,55.4$, $62.8,71.1,72.0,74.1,74.6,102.3,104.6,109.5,110.3,114.0,124.6,128.2,128.7,128.9,131.6$, $131.7,137.9,148.6,152.1,158.7,165.0,197.9$.

\section{2-Hydroxy-4-(4-methoxy-benzyl)-2,2-dimethyl-3a,4,5,11,12,12a-hexahydro-3b $\mathrm{H}-1,3,7,9-$ tetraoxa-4-aza-dicyclopenta[a,h] phenanthrene-10b-carboxylic Acid Methyl Ester (51)}

To a solution of $0.05 \mathrm{~g}(0.1 \mathrm{mmol})$ of alcohol 14 in a mixture containing $2 \mathrm{~mL}$ of $\mathrm{CH}_{2} \mathrm{Cl}_{2}$ and $1 \mathrm{~mL}$ of THF at $-78^{\circ} \mathrm{C}$ was added dropwise $0.4 \mathrm{~mL}(0.4 \mathrm{mmol})$ of DIBAL $(1.0 \mathrm{M}$ in $\mathrm{CH}_{2} \mathrm{Cl}_{2}$ ). The reaction mixture was stirred at this temperature for $1 \mathrm{~h}$ and was quenched by the addition of $0.4 \mathrm{~g}$ of powdered $\mathrm{Na}_{2} \mathrm{SO}_{4} \cdot 10 \mathrm{H}_{2} \mathrm{O}$ and $0.4 \mathrm{~g}$ Celite. The reaction mixture was warmed to rt, stirred for an additional $20 \mathrm{~min}$, and filtered through a pad of anhydrous $\mathrm{MgSO}_{4}$. The filtrate was concentrated under reduced pressure and subjected to flash silica gel chromatography to give $0.04 \mathrm{~g}(91 \%)$ of $\mathbf{5 1}$ as a colorless oil; IR (neat) 3400, 1727, 1511, 1487, 1240 , and $1039 \mathrm{~cm}^{-1 ;}{ }_{1} \mathrm{H}-\mathrm{NMR}\left(\mathrm{CDCl}_{3}, 400 \mathrm{MHz}\right) \delta 1.40(\mathrm{~s}, 3 \mathrm{H}), 1.53(\mathrm{~s}, 3 \mathrm{H}), 1.97(\mathrm{dd}, 1 \mathrm{H}$, $J=13.2$ and $10.4 \mathrm{~Hz}), 2.23(\mathrm{~d}, 1 \mathrm{H}, J=8.4 \mathrm{~Hz}), 2.66(\mathrm{dd}, 1 \mathrm{H}, J=13.2$ and $5.0 \mathrm{~Hz}), 2.83(\mathrm{~d}$, $1 \mathrm{H}, J=8.8 \mathrm{~Hz}), 3.27(\mathrm{~d}, 1 \mathrm{H}, J=13.6 \mathrm{~Hz}), 3.30(\mathrm{~d}, 1 \mathrm{H}, J=15.6 \mathrm{~Hz}), 3.64(\mathrm{~s}, 3 \mathrm{H}), 3.70(\mathrm{~d}, 1 \mathrm{H}$, $J=15.6 \mathrm{~Hz}), 3.79(\mathrm{~s}, 3 \mathrm{H}), 4.14-4.20(\mathrm{~m}, 1 \mathrm{H}), 4.42(\mathrm{~d}, 1 \mathrm{H}, J=13.6 \mathrm{~Hz}), 4.56(\mathrm{dd}, 1 \mathrm{H}, J=5.6$ and $4.4 \mathrm{~Hz}), 4.92(\mathrm{dd}, 1 \mathrm{H}, J=8.8$ and $5.6 \mathrm{~Hz}), 5.89(\mathrm{~d}, 1 \mathrm{H}, J=1.4 \mathrm{~Hz}), 5.90(\mathrm{~d}, 1 \mathrm{H}, J=1.4$ $\mathrm{Hz}), 6.34(\mathrm{~s}, 1 \mathrm{H}), 6.81(\mathrm{~d}, 2 \mathrm{H}, J=8.8 \mathrm{~Hz}), 6.89(\mathrm{~s}, 1 \mathrm{H})$, and $7.24(\mathrm{~d}, 2 \mathrm{H}, J=8.8 \mathrm{~Hz}) ;{ }^{13} \mathrm{C}-$ NMR $\left(\mathrm{CDCl}_{3}, 100 \mathrm{MHz}\right) \delta 26.4,28.5,37.2,51.8,52.5,55.4,56.9,57.3,66.4,67.0,76.1,76.6$, $101.1,105.9,107.5,109.1,113.8,128.8,129.7,130.5,132.6,146.3,146.8,158.6$, and 174.3.

\section{2-Benzyloxy-4-(4-methoxy-benzyl)-2,2-dimethyl-3b,4,10b,11,12,12a- hexahydro-3aH-1,3,7,9-tetraoxa-4-aza-dicyclopenta[a,h]phenanthren-5-one (52)}

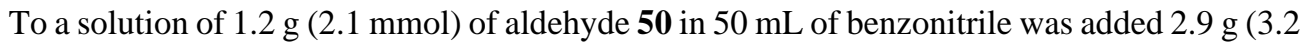
$\mathrm{mmol})$ of $\mathrm{RhCl}\left(\mathrm{PPh}_{3}\right)_{3}$. The mixture was heated at reflux in a preheated oil bath for $24 \mathrm{~h}$. After cooling to room temperature, the mixture was subjected to flash silica gel chromatography to give $0.73 \mathrm{~g}(63 \%)$ of amide $\mathbf{5 2}$ as a pale yellow oil; IR (neat) 1647, 1512, 1457, 1245, and 1040 $\mathrm{cm}^{-1 ;}{ }_{1} \mathrm{H}-\mathrm{NMR}\left(\mathrm{CDCl}_{3}, 600 \mathrm{MHz}\right) \delta 1.37(\mathrm{~s}, 3 \mathrm{H}), 1.40(\mathrm{~s}, 3 \mathrm{H}), 1.86(\mathrm{q}, 1 \mathrm{H}, J=12.6 \mathrm{~Hz}), 2.42$ (dt, $1 \mathrm{H}, J=12.6$ and $3.6 \mathrm{~Hz}), 2.63(\mathrm{td}, 1 \mathrm{H}, J=12.6$ and $3.6 \mathrm{~Hz}), 3.65-3.72(\mathrm{~m}, 2 \mathrm{H}), 4.20$ (dd, $1 \mathrm{H}, J=8.4$ and $4.8 \mathrm{~Hz}), 4.36(\mathrm{t}, 1 \mathrm{H}, J=4.8 \mathrm{~Hz}), 4.72(\mathrm{~s}, 2 \mathrm{H}), 4.88(\mathrm{~d}, 1 \mathrm{H}, J=15.6 \mathrm{~Hz}), 5.27$ $(\mathrm{d}, 1 \mathrm{H}, J=15.6 \mathrm{~Hz}), 6.02(\mathrm{~s}, 1 \mathrm{H}), 6.78(\mathrm{~s}, 1 \mathrm{H}), 6.80(\mathrm{~d}, 2 \mathrm{H}, J=8.4 \mathrm{~Hz}), 7.20(\mathrm{~d}, 2 \mathrm{H}, J=8.4$ $\mathrm{Hz}), 7.29-7.32(\mathrm{~m}, 1 \mathrm{H}), 7.34-7.39(\mathrm{~m}, 4 \mathrm{H})$, and $7.61(\mathrm{~s}, 1 \mathrm{H}) ;{ }^{13} \mathrm{C}-\mathrm{NMR}\left(\mathrm{CDCl}_{3}, 150 \mathrm{MHz}\right)$ $\delta$ 26.6, 27.5, 28.3, 36.4, 46.0, 55.5, 62.7, 71.2, 73.5, 74.8, 76.6, 101.9, 104.1, 109.0, 110.3, 
114.0, 123.5, 128.1, 128.2, 128.3, 128.8, 132.4, 134.9, 138.0, 147.2, 151.3, 158.5, and 165.7; HRMS Calcd for $\left[\left(\mathrm{C}_{32} \mathrm{H}_{33} \mathrm{NO}_{7}\right)+\mathrm{H}\right]^{+}$544.2330, Found: 544.2320.

\section{4-(4-Methoxy-benzyl)-2,2-dimethyl-3b,4,10b,12a-tetrahydro-3aH-1,3,7,9-tetraoxa-4-aza- dicyclopenta[a, $h]$ phenanthren-5-one (53)}

To a solution of $0.30 \mathrm{~g}(0.55 \mathrm{mmol})$ of $\mathbf{5 2}$ in $8 \mathrm{~mL}$ of de-gassed EtOAc was added $0.15 \mathrm{~g}$ of Pearlman's catalyst $\left(20 \% \mathrm{Pd}(\mathrm{OH})_{2}\right.$ on carbon). The reaction mixture was stirred at $\mathrm{rt}$ under a $\mathrm{H}_{2}$ balloon for $6 \mathrm{~h}$, filtered through a pad of celite, concentrated under reduced pressure and the residue was taken up in $15 \mathrm{~mL}$ of THF. To the above solution at $0{ }^{\circ} \mathrm{C}$ was added $0.07 \mathrm{~g}$ $(1.6 \mathrm{mmol})$ of $\mathrm{NaH}$ (60\% dispersion in mineral oil) in several portions. After stirring for 10 $\mathrm{min}$, the cooling bath was removed and the solution was stirred at $\mathrm{rt}$ for $40 \mathrm{~min}$. The reaction mixture was cooled to $0{ }^{\circ} \mathrm{C}$ and $85 \mu \mathrm{L}(3.3 \mathrm{mmol})$ of $\mathrm{CS}_{2}$ was added. After stirring at $0{ }^{\circ} \mathrm{C}$ for $1 \mathrm{~h}, 0.2 \mathrm{~mL}(6.6 \mathrm{mmol})$ of methyl iodide was added and the resulting mixture was stirred at 0 ${ }^{\circ} \mathrm{C}$ for $10 \mathrm{~min}$ and then at $\mathrm{rt}$ for $8 \mathrm{~h}$. The reaction mixture was quenched with a saturated $\mathrm{NH}_{4} \mathrm{Cl}$ solution and extracted with EtOAc. The combined organic layers were washed with $\mathrm{H}_{2} \mathrm{O}$, brine, and dried over $\mathrm{MgSO}_{4}$. After removing the solvent under reduced pressure, the residue was taken up in $20 \mathrm{~mL}$ of o-dichloro-benzene and was heated at reflux for $24 \mathrm{~h}$. After cooling to rt, the reaction mixture was subjected to flash silica gel chromatography to give 0.21 $\mathrm{g}(85 \%)$ of alkene $\mathbf{5 3}$ as a white solid; $\mathrm{mp} 171-173{ }^{\circ} \mathrm{C}$; IR (neat) 2924, 1645, 1511,1456, 1246, and $1038 \mathrm{~cm}^{-1 ; 1} \mathrm{H}-\mathrm{NMR}\left(\mathrm{CDCl}_{3}, 400 \mathrm{MHz}\right) \delta 1.34(\mathrm{~s}, 6 \mathrm{H}), 3.46(\mathrm{dd}, 1 \mathrm{H}, J=11.6$ and 3.0 $\mathrm{Hz}$ ), $3.64(\mathrm{dd}, 1 \mathrm{H}, J=11.6$ and $9.0 \mathrm{~Hz}), 3.77(\mathrm{~s}, 3 \mathrm{H}), 4.37(\mathrm{dd}, 1 \mathrm{H}, J=9.0$ and $7.0 \mathrm{~Hz}), 4.59-$ $4.62(\mathrm{~m}, 1 \mathrm{H}), 4.95(\mathrm{~d}, 1 \mathrm{H}, J=15.6 \mathrm{~Hz}), 5.40(\mathrm{~d}, 1 \mathrm{H}, J=15.6 \mathrm{~Hz}), 6.03(\mathrm{~s}, 2 \mathrm{H}), 6.09(\mathrm{dt}, 1 \mathrm{H}$, $J=10.0$ and $3.0 \mathrm{~Hz}), 6.32(\mathrm{~d}, 1 \mathrm{H}, J=10.0 \mathrm{~Hz}), 6.81(\mathrm{~d}, 2 \mathrm{H}, J=8.8 \mathrm{~Hz}), 6.90(\mathrm{~s}, 1 \mathrm{H}), 7.25(\mathrm{~d}$, $2 \mathrm{H}, J=8.8 \mathrm{~Hz})$, and $7.65(\mathrm{~s}, 1 \mathrm{H}) ;{ }^{13} \mathrm{C}-\mathrm{NMR}\left(\mathrm{CDCl}_{3}, 100 \mathrm{MHz}\right) \delta 25.4,27.7,38.7,45.9,55.4$, 60.9, 72.0, 75.0, 101.9, 103.9, 109.3, 109.4, 113.8, 123.8, 126.2, 128.1, 128.4, 132.7, 133.8, 147.0, 151.2, 158.4, and 165.6; HRMS Calcd for $\left[\left(\mathrm{C}_{2} 5 \mathrm{H}_{25} \mathrm{NO}_{6}\right)+\mathrm{H}\right]^{+}: 436.1755$. Found: 436.1757.

\section{1,12-Dihydroxy-4-(4-Methoxy-benzyl)-2,2-dimethyl-3b,4,10b,11,12,12a-hexa hydro-3aH-1,3,7,9-tetraoxa-4-aza-dicyclopenta[a,h]phenanthren-5-one (54)}

To a solution of $0.15 \mathrm{~g}(0.34 \mathrm{mmol})$ of $\mathbf{5 3}$ in $20 \mathrm{~mL}$ of acetone and $2 \mathrm{~mL}$ of $\mathrm{H}_{2} \mathrm{O}$ was added $\mathrm{NMO}$ ( $N$-methyl morpholine- $\mathrm{N}$-oxide) and catalytic $\mathrm{OsO}_{4}$. The mixture was stirred at $\mathrm{rt}$ for 24 $h$ and then quenched with a saturated $\mathrm{Na}_{2} \mathrm{~S}_{2} \mathrm{O}_{3}$ solution in EtOAc. The combined organic layers were washed with brine, dried over $\mathrm{MgSO}_{4}$, and concentrated under reduced pressure. The residue was subjected to flash silica gel chromatography to give $0.11 \mathrm{~g} \mathrm{(68 \% )} \mathrm{of} \mathrm{diol} \mathbf{5 4}$ as a pale yellow oil; IR (neat) 3401, 1642, 1610, 1511, 1462, 1247, and $1036 \mathrm{~cm}^{-1 ; 1} \mathrm{H}-\mathrm{NMR}$ $\left(\mathrm{CDCl}_{3}, 400 \mathrm{MHz}\right) \delta 1.24(\mathrm{~s}, 3 \mathrm{H}), 1.51(\mathrm{~s}, 3 \mathrm{H}), 2.60(\mathrm{~d}, 1 \mathrm{H}, J=2.0 \mathrm{~Hz}), 3.01(\mathrm{dd}, 1 \mathrm{H}, J=14.8$ and $7.2 \mathrm{~Hz}$ ), $3.23(\mathrm{~s}, 1 \mathrm{H}), 3.73(\mathrm{ddd}, 1 \mathrm{H}, J=10.8,5.2$, and $2.0 \mathrm{~Hz}), 3.77(\mathrm{~s}, 3 \mathrm{H}), 3.85(\mathrm{dd}, 1 \mathrm{H}$, $J=14.8$ and $7.2 \mathrm{~Hz}), 4.22(\mathrm{dd}, 1 \mathrm{H}, J=10.8$ and $7.2 \mathrm{~Hz}), 4.30(\mathrm{dd}, 1 \mathrm{H}, J=7.2$ and $5.2 \mathrm{~Hz})$, $4.38(\mathrm{t}, 1 \mathrm{H}, J=7.2 \mathrm{~Hz}), 4.67(\mathrm{~d}, 1 \mathrm{H}, J=15.2 \mathrm{~Hz}), 5.29(\mathrm{~d}, 1 \mathrm{H}, J=15.2 \mathrm{~Hz}), 6.01(\mathrm{~d}, 1 \mathrm{H}, J=$ $1.2 \mathrm{~Hz}), 6.02(\mathrm{~d}, 1 \mathrm{H}, J=1.2 \mathrm{~Hz}), 6.80(\mathrm{~d}, 1 \mathrm{H}, J=8.8 \mathrm{~Hz}), 7.24(\mathrm{~s}, 1 \mathrm{H}), 7.26(\mathrm{~d}, 1 \mathrm{H}, J=8.8$ $\mathrm{Hz})$, and $7.60(\mathrm{~s}, 1 \mathrm{H}) ;{ }^{13} \mathrm{C}-\mathrm{NMR}\left(\mathrm{CDCl}_{3}, 100 \mathrm{MHz}\right) \delta 25.6,28.1,41.9,46.9,55.4,57.8,69.5$, 70.7, 75.0, 77.1, 101.8, 106.0, 108.2, 110.6, 113.8, 122.1, 128.7, 131.6, 134.6, 147.3, 151.7, 158.7, and 165.0; HRMS Calcd for $\left[\left(\mathrm{C}_{25} \mathrm{H}_{27} \mathrm{NO}_{8}\right)+\mathrm{H}\right]^{+}: 470.1809$. Found: 470.1808.

\section{Preparation of Hexacyclic Cyclosulfate (55)}

To a solution of $0.05 \mathrm{~g}(0.11 \mathrm{mmol})$ of diol 54 in $3 \mathrm{~mL}$ of $\mathrm{CH}_{2} \mathrm{Cl}_{2}$ at $0{ }^{\circ} \mathrm{C}$ was added $62 \mu \mathrm{L}$ $(0.44 \mathrm{mmol})$ of $\mathrm{Et}_{3} \mathrm{~N}$ and $12 \mu \mathrm{L}(0.17 \mathrm{mmol})$ of $\mathrm{SOCl}_{2}$. After stirring at $0{ }^{\circ} \mathrm{C}$ for $5 \mathrm{~min}$, the cooling bath was removed and the reaction mixture was stirred at $\mathrm{rt}$ for $40 \mathrm{~min}$. The mixture was quenched with a saturated $\mathrm{NaHCO}_{3}$ solution and extracted with $\mathrm{CH}_{2} \mathrm{Cl}_{2}$. The combined organic layer was washed with $\mathrm{H}_{2} \mathrm{O}$, brine, and dried over $\mathrm{MgSO}_{4}$. After removal of the solvent 
under reduced pressure, the residue was taken up in $4 \mathrm{~mL}$ of $\mathrm{CH}_{3} \mathrm{CN}$, followed by the addition of $2.2 \mathrm{mg}$ of $\mathrm{RuCl}_{3} \cdot 3 \mathrm{H}_{2} \mathrm{O}(0.01 \mathrm{mmol})$. A solution of $0.05 \mathrm{~g}(0.22 \mathrm{mmol})$ of $\mathrm{NalO}_{4}$ in $1.0 \mathrm{~mL}$ of $\mathrm{H}_{2} \mathrm{O}$ was added. The mixture was stirred at $\mathrm{rt}$ for $12 \mathrm{~h}$, diluted with EtOAc and $\mathrm{H}_{2} \mathrm{O}$. The organic layer was washed with brine, dried over $\mathrm{MgSO}_{4}$, and concentrated under reduced pressure. The residue was subjected to flash silica gel chromatography to give $0.05 \mathrm{~g}$ of sulfate $55(82 \%)$ as a white solid; $\mathrm{mp} 218-220{ }^{\circ} \mathrm{C}$; IR (neat) 1648, 1511, 1460, 1396, 1248, and 1212 $\mathrm{cm}^{-1 ;}{ }^{1} \mathrm{H}-\mathrm{NMR}\left(\mathrm{CDCl}_{3}, 400 \mathrm{MHz}\right) \delta 1.25(\mathrm{~s}, 3 \mathrm{H}), 1.56(\mathrm{~s}, 3 \mathrm{H}), 3.47(\mathrm{dd}, 1 \mathrm{H}, J=14.4$ and 8.8 $\mathrm{Hz}), 3.77(\mathrm{~s}, 3 \mathrm{H}), 3.81(\mathrm{dd}, 1 \mathrm{H}, J=14.4$ and $7.2 \mathrm{~Hz}), 4.53(\mathrm{t}, 1 \mathrm{H}, J=7.2 \mathrm{~Hz}), 4.60(\mathrm{dd}, 1 \mathrm{H}$, $J=9.6$ and $7.2 \mathrm{~Hz}), 4.69(\mathrm{~d}, 1 \mathrm{H}, J=15.2 \mathrm{~Hz}), 4.83(\mathrm{dd}, 1 \mathrm{H}, J=9.6$ and $7.2 \mathrm{~Hz}), 5.23-5.29$ $(\mathrm{m}, 2 \mathrm{H}), 6.07(\mathrm{~s}, 2 \mathrm{H}), 6.81(\mathrm{~d}, 2 \mathrm{H}, J=8.8 \mathrm{~Hz}), 6.94(\mathrm{~s}, 1 \mathrm{H}), 7.23(\mathrm{~d}, 2 \mathrm{H}, J=8.8 \mathrm{~Hz}), 7.64$ (s, $1 \mathrm{H}) ;{ }^{13} \mathrm{C}-\mathrm{NMR}\left(\mathrm{CDCl}_{3}, 100 \mathrm{MHz}\right) \delta 25.4,27.9,38.8,47.1,55.5,56.8,74.0,81.6,82.9,102.4$, 105.4, 108.9, 112.2, 114.0, 122.1, 128.7, 130.0, 148.4, 152.3, 159.0, and 164.0; Anal. Calcd for $\mathrm{C}_{25} \mathrm{H}_{25} \mathrm{NO}_{10} \mathrm{~S}$ : C, 56.49; H, 4.74; N, 2.64. Found: C, 56.78; H, 4.75; N, 2.64.

\section{2,3,4-Trihydroxy-5-(4-methoxy-benzyl)-6-oxo-1,2,3,4,4a,5,6,11 b-octahydro-[1,3]dioxolo[4,5- j]phenanthridine-1-carboxylic Acid Phenyl Ester (56)}

To a solution of $0.02 \mathrm{~g}(0.04 \mathrm{mmol})$ of sulfate $55 \mathrm{in} 1.5 \mathrm{~mL}$ of DMF at rt was added $9 \mathrm{mg}(0.07$ $\mathrm{mmol})$ of benzoic acid and $0.02 \mathrm{~g}(0.06 \mathrm{mmol})$ of $\mathrm{CS}_{2} \mathrm{CO}_{3}$. After cooling to $\mathrm{rt}, 2 \mathrm{~mL}$ of THF and $3 \mathrm{~mL}$ of a $40 \% \mathrm{H}_{2} \mathrm{SO}_{4}$ solution was added and the mixture was heated at $80{ }^{\circ} \mathrm{C}$ for $6 \mathrm{~h}$, then cooled to room temperature, and diluted with $\mathrm{H}_{2} \mathrm{O}$ and EtOAc. The combined organic layer was washed with a saturated $\mathrm{NaHCO}_{3}$ solution, brine, and dried over $\mathrm{MgSO}_{4}$. The solvent was removed under reduced pressure and the residue was subjected to flash silica gel chromatography to give $16 \mathrm{mg}(75 \%)$ of $\mathbf{5 6}$ as a white solid; mp $230-231{ }^{\circ} \mathrm{C}$; IR (neat) 3420,1714, 1602, 1509, 1463, 1270, and $1034 \mathrm{~cm}^{-1} ;{ }_{1} \mathrm{H}-\mathrm{NMR}\left(\mathrm{CDCl}_{3}, 600 \mathrm{MHz}\right) \delta 2.68(\mathrm{~d}$, $1 \mathrm{H}, J=4.2 \mathrm{~Hz}), 3.04(\mathrm{~d}, 1 \mathrm{H}, J=4.2 \mathrm{~Hz}), 3.37$ (brs, $1 \mathrm{H}), 3.65(\mathrm{dd}, 1 \mathrm{H}, J=13.8$, and $4.2 \mathrm{~Hz}$ ), $3.79(\mathrm{~s}, 3 \mathrm{H}), 3.96-4.30(\mathrm{~m}, 3 \mathrm{H}), 4.95(\mathrm{~d}, 1 \mathrm{H}, J=16.2 \mathrm{~Hz}), 5.36(\mathrm{~d}, 1 \mathrm{H}, J=16.2 \mathrm{~Hz}), 5.62(\mathrm{t}$, $1 \mathrm{H}, J=3.6 \mathrm{~Hz}), 5.93(\mathrm{~d}, 1 \mathrm{H}, J=0.9 \mathrm{~Hz}), 5.95(\mathrm{~d}, 1 \mathrm{H}, J=0.9 \mathrm{~Hz}), 6.57(\mathrm{~s}, 1 \mathrm{H}), 6.85(\mathrm{~d}, 2 \mathrm{H}$, $J=9.0 \mathrm{~Hz}), 7.31(\mathrm{~d}, 2 \mathrm{H}, \mathrm{J}=8.4 \mathrm{~Hz}), 7.40(\mathrm{t}, 2 \mathrm{H}, J=8.4 \mathrm{~Hz}), 7.57(\mathrm{t}, 1 \mathrm{H}, J=8.4 \mathrm{~Hz}), 7.68(\mathrm{~s}$, $1 \mathrm{H})$, and $7.80(\mathrm{~d}, 2 \mathrm{H}, J=9.0 \mathrm{~Hz}) ;{ }^{13} \mathrm{C}-\mathrm{NMR}\left(\mathrm{DMSO}_{6}, 150 \mathrm{MHz}\right) \delta 38.9,45.1,55.0,57.1$, 67.4, 67.5, 70.4, 72.0, 101.7, 103.4, 107.7, 113.6, 123.8, 127.5, 128.6, 129.5, 129.7, 133.0, $133.4,133.5,146.3,150.5,157.6,164.3$, and 165.4.

\section{(士)-7-Deoxypancratistatin (10)}

To a solution of $13 \mathrm{mg}(0.02 \mathrm{mmol})$ of ester $\mathbf{5 6} \mathrm{in} 2 \mathrm{~mL}$ of THF at $25{ }^{\circ} \mathrm{C}$ was added $4 \mathrm{mg}(0.06$ mmol) of NaOMe. The reaction mixture was stirred at $25^{\circ} \mathrm{C}$ for $6 \mathrm{~h}$ and then the mixture was quenched with a saturated $\mathrm{NH}_{4} \mathrm{Cl}$ solution and extracted with EtOAc. The combined organic layer was washed with brine, dried over $\mathrm{MgSO}_{4}$, and concentrated under reduced pressure. The residue was taken up in $3 \mathrm{~mL}$ of de-gassed THF followed by the addition of $0.05 \mathrm{~g}(0.08$ mmol) of Pearlman's catalyst $\left(20 \% \mathrm{Pd}(\mathrm{OH})_{2}\right.$ on carbon). The mixture was stirred under a $\mathrm{H}_{2}$ atmosphere at rt overnight, filtered through celite and concentrated under reduced pressure. The crude residue was subjected to flash silica gel chromatography to give $6 \mathrm{mg}(80 \%)$ of $( \pm)$-7-deoxypancratistatin (10) as a colorless oil ${ }^{13}$; ${ }^{1} \mathrm{H}-\mathrm{NMR}\left(\mathrm{DMSO}-\mathrm{d}_{6}, 600 \mathrm{MHz}\right) \delta 2.98$ (dd, $1 \mathrm{H}, J=12.3$ and $2.1 \mathrm{~Hz}), 3.67-3.76(\mathrm{~m}, 2 \mathrm{H}), 3.82-3.86(\mathrm{~m}, 1 \mathrm{H}), 3.94-4.00(\mathrm{~m}, 1 \mathrm{H}), 4.30-$ $4.35(\mathrm{~m}, 1 \mathrm{H}), 4.79(\mathrm{~d}, 1 \mathrm{H}, J=7.4 \mathrm{~Hz}), 5.00-5.10(\mathrm{~m}, 2 \mathrm{H}), 5.36(\mathrm{~d}, 1 \mathrm{H}, J=4.0 \mathrm{~Hz}), 6.08(\mathrm{~s}$, $2 \mathrm{H}), 6.85(\mathrm{~s}, 1 \mathrm{H}), 6.91(\mathrm{~s}, 1 \mathrm{H})$, and $7.31(\mathrm{~s}, 1 \mathrm{H}) ;{ }^{13} \mathrm{C}-\mathrm{NMR}\left(\mathrm{DMSO}_{6}, 150 \mathrm{MHz}\right) \delta 40.1,50.4$, $68.7,70.2,70.3,73.3,101.5,105.5,106.7,123.8,135.3,145.8,150.5$, and 164.0.

\section{Supplementary Material}

Refer to Web version on PubMed Central for supplementary material. 


\section{Acknowledgements}

This research was supported by the National Institutes of Health (GM 0539384) and the National Science Foundation (CHE-0450779). We thank our colleague, Dr. Kenneth Hardcastle, for his assistance with the X-ray crystallographic studies.

\section{References}

1. Martin, SF. The Amaryllidaceae Alkaloids, Chapter 3. In: Brossi, A., editor. The Alkaloids. 30. Academic Press; New York: 1987. p. 251

2. Lewis JR. Nat Prod Rep 1994;11:329. [PubMed: 15200017]

3. (a) Leven M, Van den Berghe DA, Vlietnck AJ. Planta Med 1983;49:109. (b) Pettit GR, Gaddamidi V, Goswami A, Cragg GM. J Nat Prod 1984;47:796. [PubMed: 6512532] (c) Rivera G, Gosalbez M, Ballesta JPG. Biochem Biophys Res Commun 1980;94:800. [PubMed: 6994730]

4. Cook, JW.; Loudon, JD. The Alkaloids. Manske, RHF.; Holmes, HL., editors. 2. Academic Press; New York: 1952. p. 331

5. Ghosal S, Saini KS, Razdan S. Phytochem 1985;24:2141.

6. (a) Takagi S, Taylor WI, Uyeo S, Yajima H. J Chem Soc 1955:4003. (b) Fales HM, Warnhoff EM, Wildman WC. J Am Chem Soc 1955;77:5885.

7. (a) Tokhtabaeva GM, Sheichenko VI, Yartseva IV, Talkachev ON. Khim Prir Soedin 1987:872. (b) Richomme P, Pabuccuoglu V, Gözler T, Freyer AJ, Shamma MJ. J Nat Prod 1989;52:1150.

8. Polt, R. In Organic Synthesis: Theory and Applications. Hudlicky, T., editor. 3. JAI Press; Greenwich, CT: 1997. p. 109Hoshino, O. The Alkaloids. Cordell, GA., editor. 51. Academic Press; New York: 1998. p. 323 (c) Jin Z. Nat Prod Rep 2003;20:606. [PubMed: 14700202]

9. Rinner U, Hudlicky T. Synlett 2005:365.

10. For syntheses of Lycoricidine, see: (a) Ohta S, Kimoto S. Chem Pharm Bull 1976;24:2977. (b) Paulsen H, Stubbe M. Tetrahedron Lett 1982;23:3171. (c) Paulsen H, Stubbe M. Liebigs Ann Chem 1983:535. (d) Chida N, Ohtsuka M, Ogawa S. Tetrahedron Lett 1991;32:4525. (e) Hudlicky T, Olivo HF. J Am Chem Soc 1992;114:9694. (f) Chida N, Ohtsuka M, Ogawa S. J Org Chem 1993;58:4441. (g) Martin SF, Tso HH. Heterocycles 1993;35:85. (h) Hudlicky T, Olivo HF, McKibben B. J Am Chem Soc 1994;116:5108. (i) Keck GE, Wager TT. J Org Chem 1996;61:8366. (j) Elango S, Van TH. Tetrahedron 2002;58:7375.

11. For syntheses of Narciclasine, see: (a) Mondon A, Krohn K. Tetrahedron Lett 1972;13:2085. (b) Mondon A, Krohn K. Chem Ber 1975;108:445. (c) Krohn K, Mondon A. Chem Ber 1976;109:855. (d) Rigby JH, Mateo ME. J Am Chem Soc 1997;119:12655. (e) Rigby JH, Maharoof USM, Mateo ME. J Am Chem Soc 2000;122:6624. (f) Gonzalez D, Martinet T, Hudlicky T. Tetrahedron Lett 1999;40:3077.

12. For syntheses of Pancratistatin, see: (a) Danishefsky S, Lee JY. J Am Chem Soc 1989;111:4829. (b) Tian X, Hudlicky T, Königsberger K. J Am Chem Soc 1995;117:3643. (c) Trost BM, Pulley SR. J Am Chem Soc 1995;117:10143. (d) Keck GE, McHardy SF, Murry JA. J Am Chem Soc 1995;117:7289. (e) Hudlicky T, Tian XR, Königsberger K, Mauray R, Rouden J, Fan B. J Am Chem Soc 1996;118:10752. (f) Chida N, Jitsuoka M, Yamamoto Y, Ohtsuka M, Ogawa S. Heterocycles 1996;43:1385. (g) Doyle TJ, Hendrix M, VanDerveer D, Javanmard S, Haseltine J. Tetrahedron 1997;53:11153. (h) Magnus P, Sebhat IK. Tetrahedron 1998;54:15509. (i) Magnus P, Sebhat IK. J Am Chem Soc 1998;120:5341. (j) Pettit GR, Melody N, Herald DL. J Org Chem 2001;66:2583. [PubMed: 11304174] (k) Kim S, Ko H, Kim E, Kim D. Org Lett 2002;4:1343. [PubMed: 11950358] (I) Ko HJ, Park JE, Kim S. J Org Chem 2004;69:112. [PubMed: 14703386]

13. (a) Akgun H, Hudlicky T. Tetrahedron Lett 1999;40:3081. (b) Rinner U, Siengalewicz P, Hudlicky T. Org Lett 2002;4:115. [PubMed: 11772104] (c) Tian X, Maurya R, Königsberger K. Synlett 1995:1125. (d) Keck GE, Wager TT, McHardy SF. J Org Chem 1998;63:9164. (e) Keck GE, McHardy SF, Murry JA. J Am Chem Soc 1995;117:7239. (f) Acena JL, Arjona O, Leon ML, Plumet J. Org Lett 2000;2:3683. [PubMed: 11073675]

14. Pettit GR, Backhaus RA, Boettner FE. J Nat Prod 1995;58:37. [PubMed: 7760076]

15. (a) Pettit GR, Freeman S, Simpson MJ, Thompson MA, Boyd MR, Williams GR, Pettit GR III, Doubek DL. Anti-Cancer Drug Des 1995;10:243. (b) Pettit GR, Orr S, Ducki S. Anti-Cancer Drug Des 2000;15:389. (c) Pettit GR, Pettit GR III, Backaus RA, Boyd MR, Meerow AW. J Nat Prod 
1993;56:1682. [PubMed: 8277308] (d) Pettit GR, Pettit GR III, Backaus RA, Boyd MR, Meerow AW. J Nat Prod 1993;56:1682. [PubMed: 8277308] (e) Hudlicky T, Rinner U, Gonzalez D, Akgun H, Schilling S, Siengalewicz P, Martinet TA, Pettit GR. J Org Chem 2002;67:8726. [PubMed: 12467383]

16. Hudlicky T. J Heterocycl Chem 2000;37:535.

17. For some leading references, see: González C, Pérez D, Guitián E, Castedo L. J Org Chem 1995;60:6318.

18. (a) Hill RK, Joule JA, Loeffler L. J Am Chem Soc 1962;84:4951. (b) Tsuda Y, Sano T, Taga J, Isobe K, Toda J, Irie H, Tanaka H, Takagi S, Yamaki S, Murata M. J Chem Soc, Chem Commun 1975:933. (c) Hwang G, Magnus P. J Chem Soc, Chem Commun 1983:693.

19. (a) Oppolzer W. Angew Chem, Int Ed 1977;16:10. (b) Oppolzer W. Synthesis 1978:793. (c) Oppolzer W. Heterocycles 1980;14:1615. (d) Brieger G, Bennett JN. Chem Rev 1980;80:63.

20. Craig D. Chem Soc Rev 1987;16:187.

21. Kappe CO, Murphree SS, Padwa A. Tetrahedron 1997;53:14179.and references cited therein

22. Lipshutz B. Chem Rev 1986;86:795.

23. (a) Sternbach DD, Rossana DM, Onan KD. J Org Chem 1984;49:3427. (b) Klein LL. J Org Chem 1985;50:1770. (c) Jung ME, Gervay J. J Am Chem Soc 1989;111:5469.

24. (a) Padwa A, Brodney MA, Dimitroff M. J Org Chem 1998;63:5304. (b) Padwa A, Brodney MA, Satake K, Straub CS. J Org Chem 1999;64:4617. [PubMed: 11674531]

25. (a) Wang Q, Padwa A. Org Lett 2004;6:2189. [PubMed: 15200317] (b) Padwa A, Ginn JD. J Org Chem 2005;70:5197. [PubMed: 15960524] (c) Padwa A, Bur SK, Zhang H. J Org Chem 2005;70:6833. [PubMed: 16095303] (d) Wang Q, Padwa A. Org Lett 2006;8:601. [PubMed: 16468721] (e) Padwa A, Wang Q. J Org Chem 2006;71:7391. [PubMed: 16958534]

26. Farina V, Krishnamurphy V, Scott WJ. Org React 1997;50:1.

27. For a preliminary report see: Zhang H, Padwa A. Org Lett 2006;8:247. [PubMed: 16408886]

28. (a) Zhang HX, Guiibe F, Balavoine G. J Org Chem 1990;55:1857. (b) Miyake H, Yamamura K. Chem Lett 1989:981. (c) Cochran JC, Bronk BS, Terrence KM, Philips HK. Tetrahedron Lett 1990;31:6621.

29. Mee PH, Lee V, Baldwin JE. Angew Chem, Int Ed 2004;43:1132.

30. Nace HR. Org React 1962;12:57.

31. For a related fragmentation reaction, see: Khim S, Dai M, Zhang X, Chen L, Pettus L, Thakkar K, Schultz AG. J Org Chem 2004;69:7728. [PubMed: 15498003]

32. McIntosh MC, Weinreb SM. J Org Chem 1993;58:4823.

33. Replacement of the Boc group with the PMB functionality was necessary for the subsequent Stille reaction.

34. Han X, Stoltz BM, Corey EJ. J Am Chem Soc 1999;121:7600.

35. (a) Oppolzer W, Fröstl W. Helv Chem Acta 1975;58:590. (b) White JD, Demnitz FWJ, Oda H, Hassler C, Snyder JP. Org Lett 2000;2:3313. [PubMed: 11029198] (c) Padwa A, Ginn JD, Bur SK, Eidell CK, Lynch SM. J Org Chem 2002;67:3412. [PubMed: 12003554] (d) Tantillo DJ, Houk KN, Jung ME. J Org Chem 2001;66:1938. [PubMed: 11300884]

36. Gensler WJ, Johnson F, Sloan ADB. J Am Chem Soc 1960;82:6074.

37. Keck GE, Boden E, Sonnewald U. Tetrahedron Lett 1981;22:2615.

38. (a) Pettit GR, Gaddamidi D, Herald L, Singh SB, Gragg GM, Schmidt JM. J Nat Prod 1986;46:995. [PubMed: 3572427]Gabrielson, B.; Monath, TP.; Huggins, JW.; Kirsi, JJ.; Hollingshead, M.; Shannon, WM.; Pettit, GR. Natural Products as Antiviral Agents. Chu, CK.; Cutler, HG., editors. Plenum; New York: 1992. p. 121 (c) Ghosal S, Singh S, Kumar Y, Srivastava RS. Phytochemistry 1989;28:611.

39. (a) Gabrielsen B, Monath TP, Huggins JW, Pettit GR, Kirsi JJ, Schubert EM, Dare J, Ussery MA. J Nat Prod 1992;55:1569. [PubMed: 1336040] (b) Pettit GR, Pettit GR III, Groszek RA, Backhaus RA, Doubek DL, Barr RJ, Meerow AW. J Nat Prod 1995;58:756. [PubMed: 7623049]

40. For some selected examples, see: (a) Fleet GWJ, Ramsden NG, Witty DR. Tetrahedron 1989;45:319. (b) Arjona O, Iradier F, Plumet J, Martnez-Alcazar MP, Hernandez-Cano F, Fonseca I. Tetrahedron Lett 1998;39:6741. (c) Rinner U, Siengalwicz P, Hudlicky T. Org Lett 2001;4:115. [PubMed: 11772104] (d) Hudlicky T, Rinner U, Gonzalez D, Akgun H, Schilling S, Siengalewicz P, Martinot 
TA, Pettit GR. J Org Chem 2002;67:8726. [PubMed: 12467383] (e) Rinner U, Hillebrenner H, Adams DR, Hudlicky T, Pettit GR. Bioorg Med Chem Lett 2004;14:2911. [PubMed: 15125958] (f) McNulty J, Mao J, Gibe R, Mo R, Wolf S, Pettit GR, Herald DL, Boyd MR. Bioorg Med Chem Lett 2001;11:169. [PubMed: 11206451] (g) Schilling S, Rinner U, Chan C, Ghiviriga I. Can J Chem 2001;79:1659. (h) Ibn-Ahmed S, Khaldi M, Chretien K, Chapleur Y. J Org Chem 2004;69:6722. [PubMed: 15387596] (i) Zhang H, Padwa A. Tetrahedron Lett 2006;47:3905.

41. (a) Rigby JH, Maharoof USM, Mateo ME. J Am Chem Soc 2000;122:6624. for a somewhat related example, see (b)ThompsonRCKallmertenJJ Org Chem1990556078

42. (a) Tsuji J, Ohno K. Synthesis 1969:157. (b) Walborsky HM, Allen LE. J Am Chem Soc 1971;93:5465.

43. (a) Ziegler FE, Belema M. J Org Chem 1997;62:1083. (b) Kato T, Hoshikawa M, Yaguchi Y, Izumi K, Uotsu Y, Sakai K. Tetrahedron 2002;58:9213. (c) Harmata M, Wacharasindhu S. Org Lett 2005;7:2563. [PubMed: 15957891] (d) Malerich JP, Maimone TJ, Elliott GI, Trauner D. J Am Chem Soc 2005;127:6276. [PubMed: 15853334]

44. A related finding had been made by the Hudlicky group in their elegant total synthesis of (+)pancratistatin. In an attempted deprotection of a $N$-tosyl amide using $\mathrm{Na}(\mathrm{Hg})$, it was observed that reduction of the lactam carbonyl group preferentially occurred and this finding was attributed to relief of ring strain. $12 \mathrm{~b}$

45. Ley SV, Norman J, Griffith WP, Marsden SP. Synthesis 1994:639.

46. (a) Gao Y, Sharpless KB. J Am Chem Soc 1988;110:7538. (b) Lohray BB. Synthesis 1992:1035.

47. See accompanying supporting information for experimental details.

48. Padwa A, Brodney MA, Lynch SM. Organic Synthesis 2002;78:202.

49. McIntosh MC, Weinreb SM. J Org Chem 1993;58:4823.

50. Keck GE, Wager TT, Rodriquez JFD. J Am Chem Soc 1999;121:5176. 
<smiles>CC1C2CCCN3Cc4ccccc4C1C23</smiles>

1; galanthan ring<smiles>C[C@@H]1c2cc3c(cc2CN2CCC4=C[C@H](O)[C@H]1[C@H]42)OCO3</smiles>

2; lycorine<smiles></smiles>

3; $\alpha$-lycorane

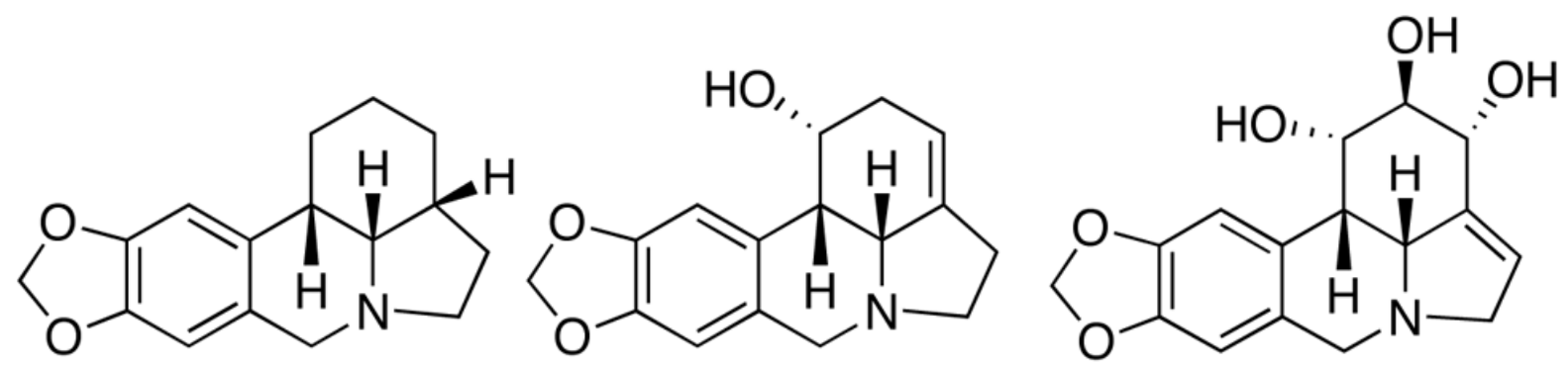

$4 ; \gamma$-lycorane

5; fortucine

6; siculinine

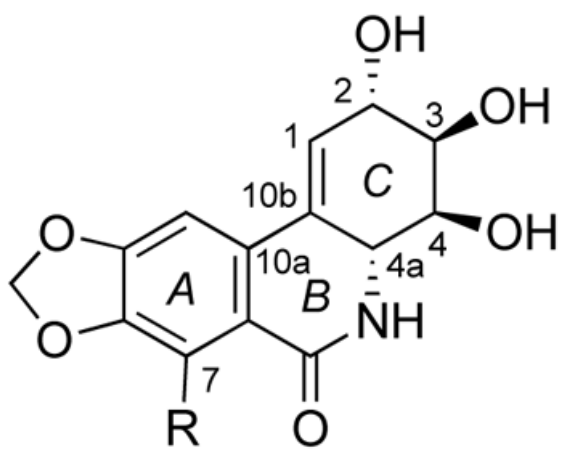

7; $\mathrm{R}=\mathrm{H}$; lycoricidine

8; $\mathrm{R}=\mathrm{OH}$; narciclasine<smiles>[R]c1c2c(cc3c1C(=O)N[C@@H]1[C@@H](O)[C@H](O)[C@H](O)[C@H](O)[C@H]31)OCO2</smiles>

9; $\mathrm{R}=\mathrm{OH}$; pancratistatin 10; $\mathrm{R}=\mathrm{H} ;$ 7-deoxypancratistatin

Figure 1.

Some Representative Lycorine-type Alkaloids 
<smiles>O=C1N[C@H]2C(=C[C@H](O)C(O)[C@@H]2O)c2cc3c(cc21)OCO3</smiles>

7; ( \pm )-Lycoricidine<smiles>[R5]N(C(=O)c1cc2c(cc1I)OCO2)c1ccco1</smiles>

11

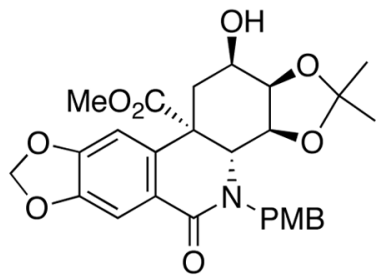

14<smiles>C1=CC=C1</smiles><smiles>C=C(CCCCC)C(C)=O</smiles><smiles>COc1c2c(cc3c1C(=O)N([PH](N)(=O)=O)C1(C=CC4CC1O4)O3)OCO2</smiles>

13

Scheme 1.

Key Disconnections for the Synthesis of $( \pm)$-Lycoricidine 
<smiles>C=C(COC)c1ccccc1C=O</smiles><smiles>C=C(COC)c1ccccc1C(=O)N(C(=O)OCc1ccccc1)c1ccco1</smiles>

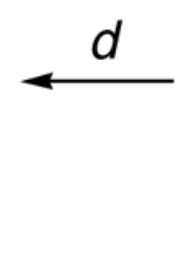<smiles>C=C(C(C)=O)c1ccccc1C(=O)O</smiles>

Reagents: (a) $\mathrm{MeO}_{2} \mathrm{CCH}_{2} \mathrm{P}(\mathrm{O})(\mathrm{OEt})_{2}, \mathrm{NaH}, \mathrm{Cul}, \mathrm{DMF}, 100^{\circ} \mathrm{C}$, 61\%; (b) $\mathrm{NaH}, \mathrm{CH}_{2} \mathrm{O}, \mathrm{THF}, 25^{\circ} \mathrm{C}, 83 \%$; (c) $\mathrm{NaClO}_{2}, \mathrm{H}_{2} \mathrm{O}_{2}$, $\mathrm{NaH}_{2} \mathrm{PO}_{4}$, acetone, $10^{\circ} \mathrm{C}, 93 \%$; (d) $(\mathrm{COCl})_{2}, \mathrm{CH}_{2} \mathrm{Cl}_{2}, n-\mathrm{BuLi}$, BocNHfuran, 65\% (2 steps).

Scheme 2. Synthesis of a Model 2-Amidofuran

Reagents: (a) $\mathrm{MeO}_{2} \mathrm{CCH}_{2} \mathrm{P}(\mathrm{O})(\mathrm{OEt})_{2}, \mathrm{NaH}, \mathrm{Cul}, \mathrm{DMF}, 100^{\circ} \mathrm{C}, 61 \%$; (b) $\mathrm{NaH}, \mathrm{CH}_{2} \mathrm{O}, \mathrm{THF}$, $25^{\circ} \mathrm{C}, 83 \%$; (c) $\mathrm{NaClO}_{2}, \mathrm{H}_{2} \mathrm{O}_{2}, \mathrm{NaH}_{2} \mathrm{PO}_{4}$, acetone, $10{ }^{\circ} \mathrm{C}, 93 \%$; (d) $(\mathrm{COCl})_{2}, \mathrm{CH}_{2} \mathrm{Cl}_{2}, n$ - $\mathrm{BuLi}$, BocNHfuran, $65 \%$ (2 steps). 
<smiles>C=C(COC)c1ccccc1C(=O)N(C(=O)OCc1ccccc1)c1ccco1</smiles>

Scheme 3.

Cycloaddition/Rearrangement Cascade
15

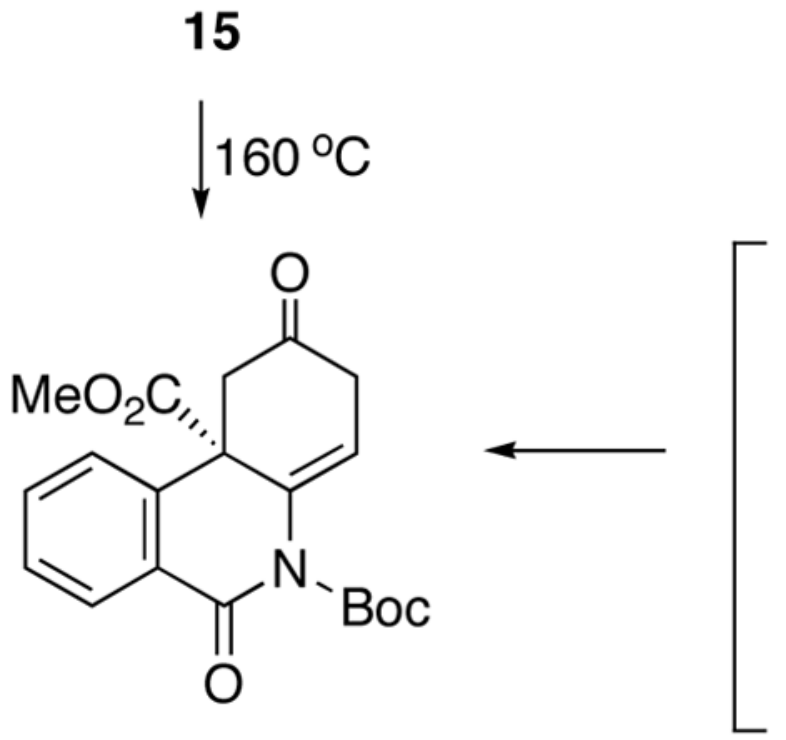

$18(80 \%)$<smiles>COC(=O)N1C(=O)c2ccccc2[C@@]2(C(=O)OCc3ccccc3)C3C=CC12O3</smiles>

$16(98 \%)$<smiles>C[13CH][13CH]</smiles>

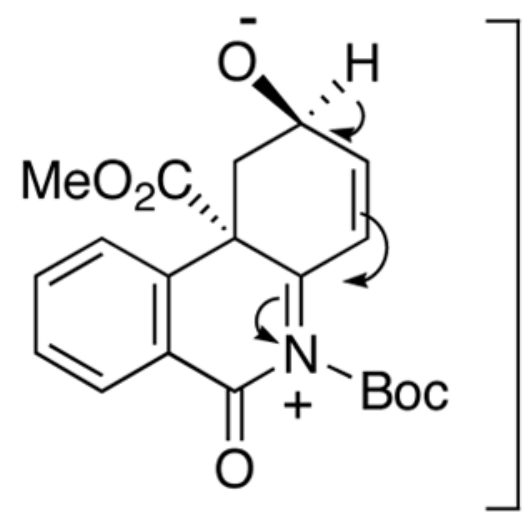

17 


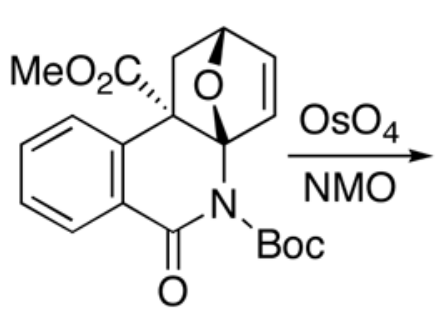

16

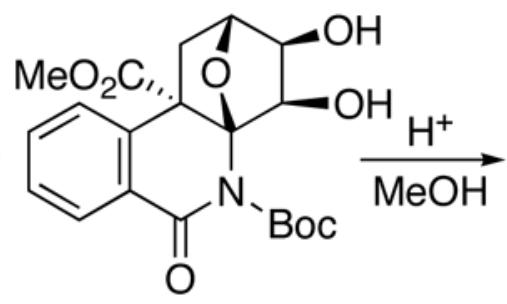

19 (95\%)<smiles>COC(=O)[C@]12CC=CC(=O)[C@]1(OC)NC(=O)c1ccccc12</smiles>

20 (81\%)

Scheme 4.

An Unusual Acid-Catalyzed Rearrangement 


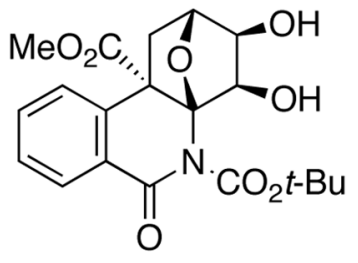

19<smiles>CCOC(=O)[C@@]12C[C@H](O)C=C(OC(=O)OC)C1=NC(=O)c1ccccc12</smiles>

23

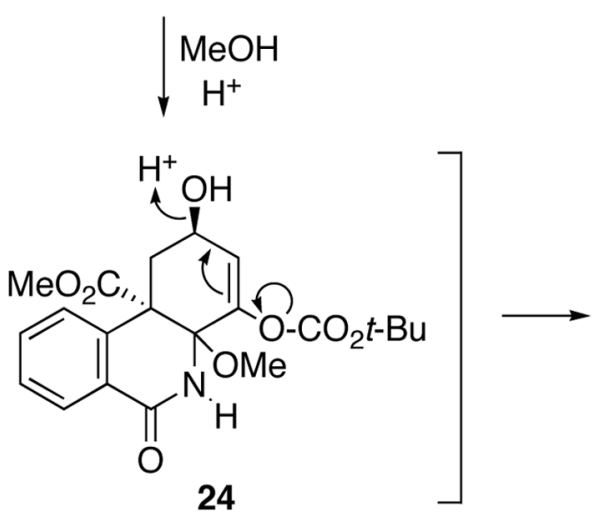

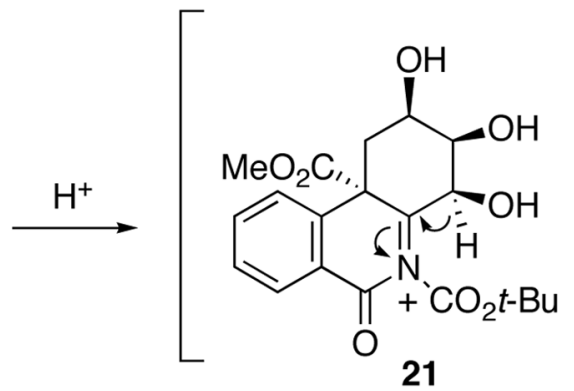

$\downarrow-\mathrm{H}^{+}$

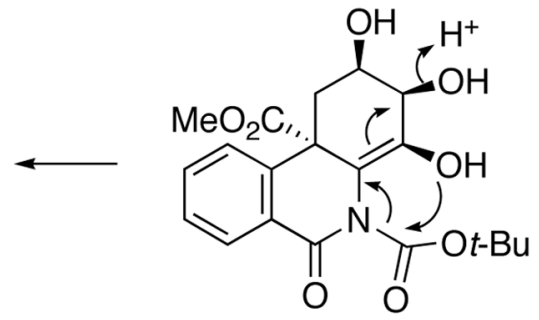

22<smiles>COC(=O)C12CC=CC(=O)C1(OC)NC(=O)c1ccccc12</smiles>

20

Scheme 5.

A Proposed Mechanism for the Rearrangement 
<smiles>COC[C@@]12C[C@H]3C=C[C@]1(O3)N(Cc1ccccc1)C(=O)c1ccccc12</smiles>

25<smiles>COC[C@@]12C[C@@H](OC)[C@@H]3OC(C)(C)O[C@@H]3[C@H]1N(Cc1ccccc1)C(=O)c1ccccc12</smiles><smiles>CC(=O)Cl</smiles>

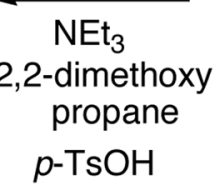

1. $\mathrm{NaOMe}$

2. $\mathrm{NaH}, \mathrm{CS}_{2}, \mathrm{Mel}$ heat<smiles>COC[C@]12C=C[C@@H]3OC(C)(C)O[C@H]3[C@@H]1N(Cc1ccccc1)C(=O)c1ccccc12</smiles>

$29(92 \%)$

Scheme 6.

Dihydroxylation of the IMDAF Cycloadduct 
<smiles>COC[C@]12C=C[C@@H]3OC(C)(C)O[C@@H]3[C@@H]1N(Cc1ccccc1)C(=O)c1ccccc12</smiles>

29<smiles>CO[C@H]1[C@@H](O)[C@@H]2OC(C)(C)O[C@@H]2[C@H]2N(Cc3ccccc3)C(=O)c3ccccc3[C@@]21CO</smiles>

33<smiles>[3H]C(=O)O[Na]</smiles>

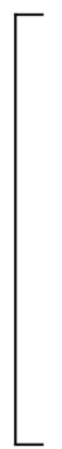<smiles>CO[C@]12c3ccccc3C(=O)N(Cc3ccccc3)[C@H]1[C@@H]1OC(C)(C)O[C@H]1[C@@H]2O</smiles><smiles>[3H][Te]</smiles>

$\frac{\mathrm{LiOH}}{\mathrm{H}_{2} \mathrm{O}}$<smiles>[R6][C@]1(O)O[C@@H]2[C@@H]3OC(C)(C)O[C@@H]3[C@@H]3N(Cc4ccccc4)C(=O)c4ccccc4[C@@]23C1=O</smiles>

$\mathrm{MsCl}$ 31; $\mathrm{R}=\mathrm{H}$

$\mathrm{NEt}_{3}$ 32; $\mathrm{R}=\mathrm{Ms}(74 \%)$<smiles>CC1(C)O[C@@H]2[C@H](O1)N(Cc1ccccc1)C(=O)C1=C[C@H](O)c3ccccc3[C@H]12</smiles>

$35(90 \%)$

Scheme 7.

Decarboxylation/Elimination Sequence 

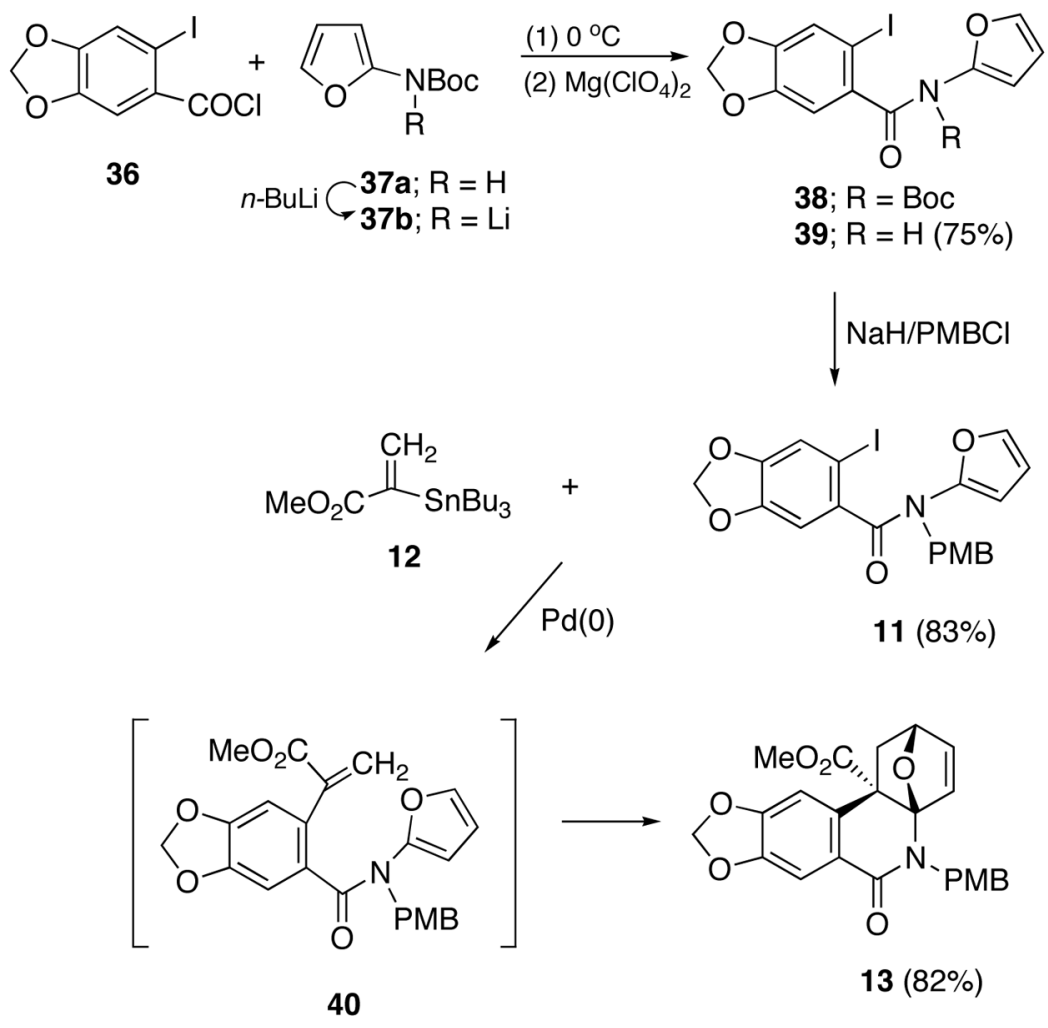

Scheme 8.

Intramolecular Diels-Alder Reaction 


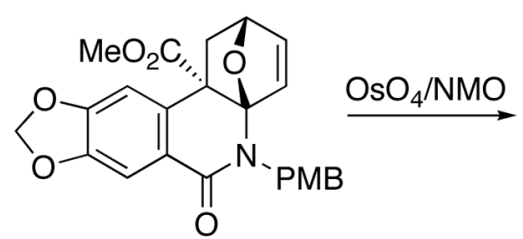

13<smiles>COC[C@@]12C[C@H]3O[C@]1([C@H](O)[C@H]2O)N([PH](C)(=O)=O)C(=O)c1cc2c(cc13)OCO2</smiles>

41 (98\%)

2,2-dimethoxypropane PPTS<smiles>COC[C@]12C[C@H](O)[C@H]3OC(C)(C)O[C@H]3[C@@H]1N([R15](=O)[O-])C(=O)c1cc3c(cc12)OCO3</smiles>

$14(74 \%)$<smiles>COC[C@]12C[C@@H]3O[C@]1(c1cc4c(cc1C(=O)N2[14CH3])OCO4)[C@H]1OC(C)(C)O[C@@H]31</smiles>

$42(80 \%)$

Scheme 9.

Stereocontrolled Reduction of $N$-Acyliminium Ion Precursor 
<smiles>COC[C@]12C[C@H](O)[C@H]3OC(C)(C)O[C@@H]3[C@@H]1N(C(C)(C)C)C(=O)c1cc3c(cc12)OCO3</smiles>

14

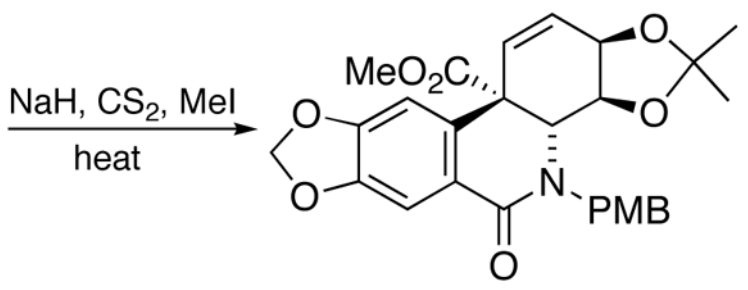

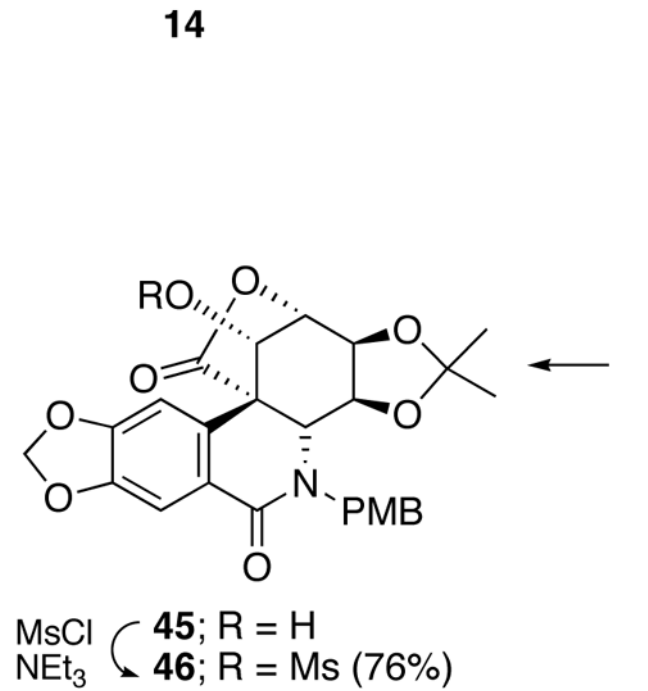

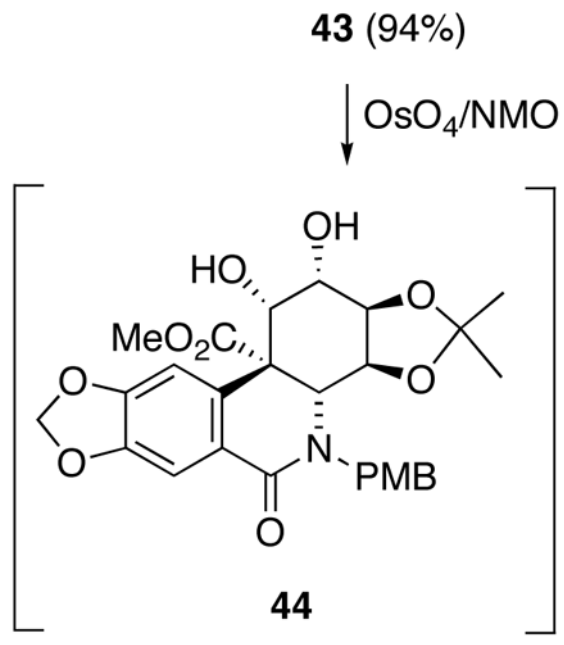

(1) $\mathrm{PdCl}_{2}, \mathrm{AcOH}$ (2) $\mathrm{LiOH}$<smiles>CC1(C)O[C@H]2NC(=O)c3cc4c(cc3[C@H]2O1)OCO4</smiles>

$47(60 \%)$<smiles>O=C1N[C@H]2C(=C[C@H](O)[C@@H](O)[C@H]2O)c2cc3c(cc21)OCO3</smiles>

7; (土)-Lycoricidine (90\%)

Scheme 10.

Final Steps in the Synthesis of ( \pm )-Lycoricidine 


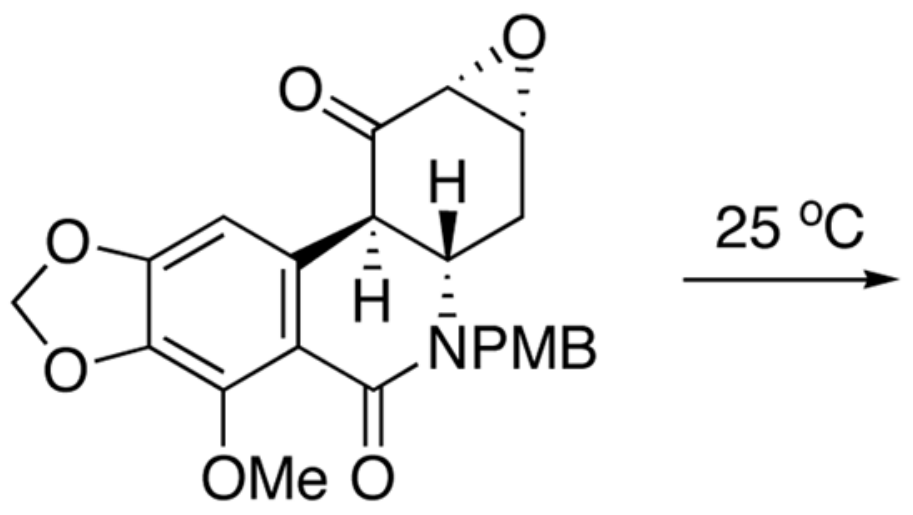

48 (trans)

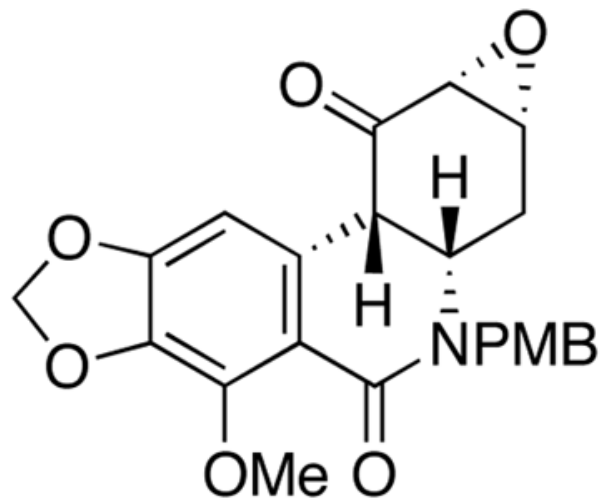

49 (cis)

Scheme 11.

Preference for the cis-Isomer 


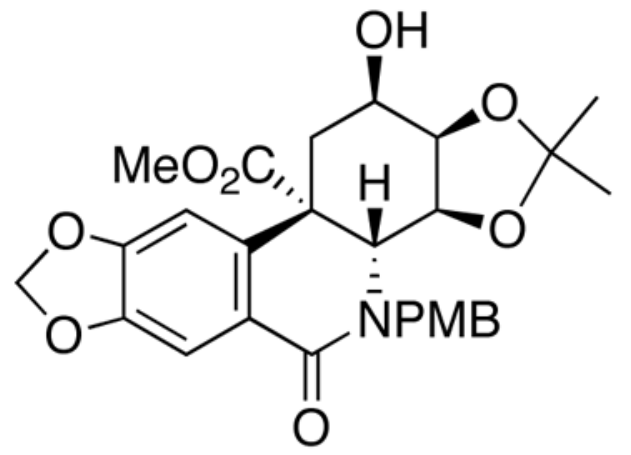

14

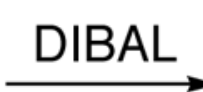

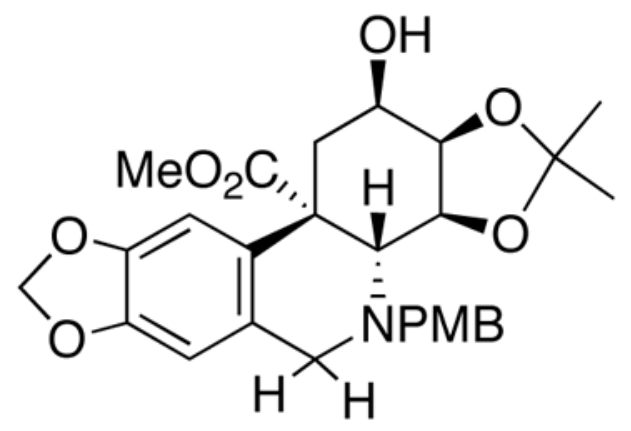

$51(91 \%)$
1. $\mathrm{NaH}, \mathrm{PhCH}_{2} \mathrm{Br}$
2. $\mathrm{LiOH} / \mathrm{THF}$
3. $(\mathrm{COCl})_{2}, \mathrm{Zn}\left(\mathrm{BH}_{4}\right)_{2}$
4. TPAP, NMO

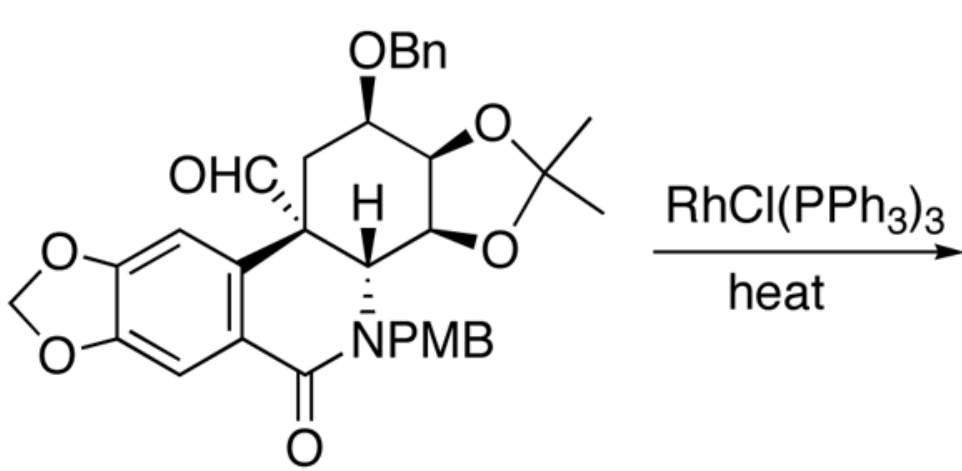

$50(70 \%)$

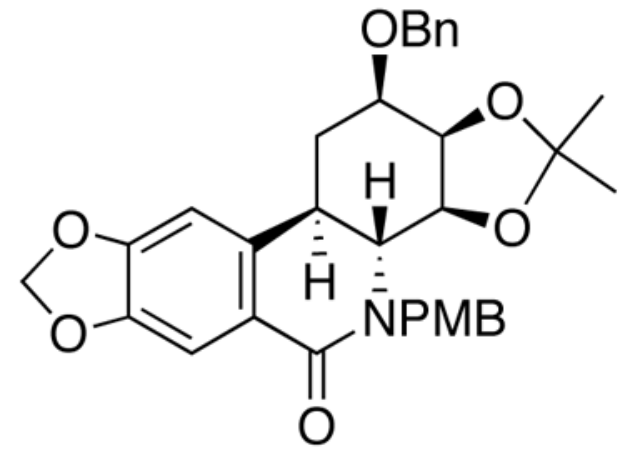

$52(63 \%)$ trans fused

Scheme 12.

Use of Wilkinson's Catalyst to Control Stereochemistry 


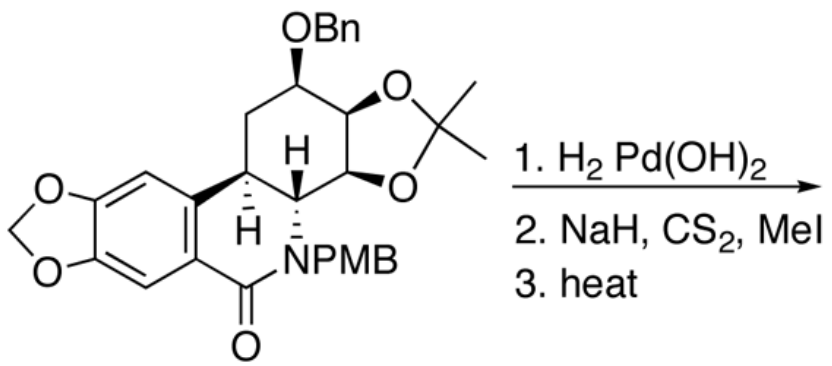

52<smiles></smiles>

55 (82\%)

1. $\mathrm{PhCO}_{2} \mathrm{Cs}$
2. $\mathrm{H}^{+}$<smiles>[R15]N1C(=O)c2cc3c(cc2[C@@H]2[C@@H](O)[C@H](O)[C@@H](O)[C@H](O)[C@@H]21)OCO3</smiles>

56 (75\%)<smiles>[R15]N1C(=O)c2cc3c(cc2[C@@H]2C=C[C@@H]4OC(C)(C)O[C@H]4[C@@H]21)OCO3</smiles>

53 (85\%)<smiles>O=[W]O[Na]</smiles>

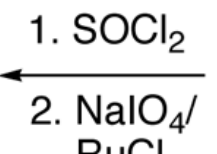
$\mathrm{RuCl}_{3}$<smiles></smiles>

54 (68\%)

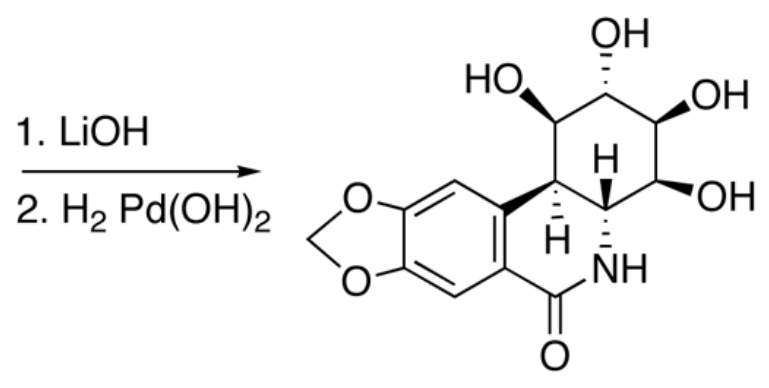

10; ( \pm )-7-deoxypancratistatin (80\%)

Scheme 13.

Synthesis of $( \pm)$-7-Deoxypancratistatin 